\title{
Synthetic Chiral Derivatives of Xanthones: Biological Activities and Enantioselectivity Studies
}

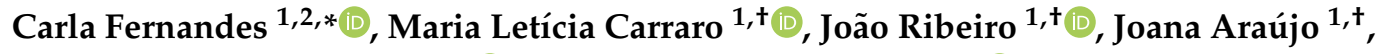
Maria Elizabeth Tiritan $1,2,3, *(1)$ and Madalena M. M. Pinto ${ }^{1,2}$ (D)

1 Laboratório de Química Orgânica e Farmacêutica, Departamento de Ciências Químicas, Faculdade de Farmácia, Universidade do Porto, Rua de Jorge Viterbo Ferreira, 228, 4050-313 Porto, Portugal; leticiacarraro@hotmail.com (M.L.C.); joaobigi@gmail.com (J.R.); up201703236@ff.up.pt (J.A.); madalena@ff.up.pt (M.M.M.P.)

2 Interdisciplinary Centre of Marine and Environmental Research (CIIMAR), Edifício do Terminal de Cruzeiros do Porto de Leixões, Av. General Norton de Matos s/n, 4050-208 Matosinhos, Portugal

3 Cooperativa de Ensino Superior, Politécnico e Universitário (CESPU), Instituto de Investigação e Formação Avançada em Ciências e Tecnologias da Saúde (IINFACTS), Rua Central de Gandra, 1317, 4585-116 Gandra PRD, Portugal

* Correspondence: elizabeth.tiritan@iucs.cespu.pt (M.E.T.); cfernandes@ff.up.pt (C.F.); Tel.: +351-22-415-7224 (M.E.T.); +351-22-042-8688 (C.F.)

+ These authors contributed equally to this work.

Academic Editor: Maurizio Benaglia

Received: 1 February 2019; Accepted: 19 February 2019; Published: 22 February 2019

\begin{abstract}
Many naturally occurring xanthones are chiral and present a wide range of biological and pharmacological activities. Some of them have been exhaustively studied and subsequently, obtained by synthesis. In order to obtain libraries of compounds for structure activity relationship (SAR) studies as well as to improve the biological activity, new bioactive analogues and derivatives inspired in natural prototypes were synthetized. Bioactive natural xanthones compromise a large structural multiplicity of compounds, including a diversity of chiral derivatives. Thus, recently an exponential interest in synthetic chiral derivatives of xanthones (CDXs) has been witnessed. The synthetic methodologies can afford structures that otherwise could not be reached within the natural products for biological activity and SAR studies. Another reason that justifies this trend is that both enantiomers can be obtained by using appropriate synthetic pathways, allowing the possibility to perform enantioselectivity studies. In this work, a literature review of synthetic CDXs is presented. The structures, the approaches used for their synthesis and the biological activities are described, emphasizing the enantioselectivity studies.
\end{abstract}

Keywords: synthetic xanthones; chiral derivatives of xanthones; bioactivities; enantioselectivity; enantiomeric purity

\section{Introduction}

In the last few years, the relationship between chirality and biological activity has been of increasing importance in Medicinal Chemistry [1]. Chirality can now be considered as one of the majors' topics in the design, discovery, development and marketing of new drugs [2-4]. Enantiomers of drugs often present different behaviours within pharmacodynamics and/or pharmacokinetics events [5-7] as well as different levels of toxicity [8-10]. These differences makes in the majority of cases therapeutics with single enantiomers of unquestionable advantages [11].

The importance of enantioselective studies and the increase of chiral drugs in the pharmaceutical market upsurges each year due to the advantages in potency, efficacy, selectivity and safety associated 
with the use of single enantiomers. The advances in enantioselective synthesis [12-15] as well as enantioresolution methodologies [16-19] aligned to the stricter requirements from regulatory authorities to patent new chiral drug [20-22] boosted the research in this field.

The development of methods to obtain and analyse both pure enantiomers has acquired crucial importance in the early stage of drug development, as biological and pharmacological activity evaluation of both enantiomers are required. Thus, despite the diversity of structures with different groups and positions at the base scaffolds, the library of compounds for structure-activity relationship (SAR) studies should also include stereoisomers for enantioselectivity evaluation. To perform that type of studies, it is necessary to obtain both enantiomers with very high enantiomeric purity. The improvement of chromatographic instrumentation and the development of efficient chiral stationary phases (CSPs) [23-26] have made liquid chromatography (LC) the first choice for determination of enantiomeric purity.

Chemically, xanthones (9H-xanthen-9-ones) are compounds with an oxygen-containing dibenzo- $\gamma$-pyrone heterocyclic scaffold [27], being considered as a privileged structure [28,29]. Within this class of compounds a broad range of biological and pharmacological activities has been reported [30-34]. Additionally, other applications have been described for xanthone derivatives, such as preparation of fluorescent probes $[35,36]$ or stationary phases for LC $[23,24,37]$.

Many naturally occurring xanthones, isolated from terrestrial as well as marine sources, are chiral, and present interesting biological activities [38-40]. The biosynthetic pathway of xanthones only allows the presence of specific groups in particular positions of the xanthone scaffold, which is a limiting factor for structural diversity. For this reason, in order to enlarge chemical space in this field, total synthesis needs to be considered [41,42] allowing the access to structures that otherwise could not be reached only with natural product as a basis for molecular modification. Moreover, higher number of compounds can be obtained for SAR studies.

\section{Synthetic Chiral Derivatives of Xanthones}

Recently, there has been an increase interest in new bioactive xanthones obtained by synthesis, particularly in chiral derivatives of xanthones (CDXs). Some reasons that can justify this trend were the importance of this class of compounds in Medicinal Chemistry align with the fact that nature usually gives only one enantiomer and the synthetic procedures allow the preparation of both enantiomers to explore the enantioselectivity in biological screening assays. The promising biological and pharmacological activities of some chiral members of this family, the clinical advantages of a single enantiomer than a racemate, the scarce examples of synthetic CDXs described, and the possibility to perform enantioselectivity studies strengthens the obtaining of new synthetic CDXs. This review aims to gather the research findings on synthetic CDXs, reporting their biological and pharmacological activities. The structures and the bioactivity differences associated to the stereochemistry of the CDXs (enantioselectivity) as well as their enantiomeric purity are highlighted.

\subsection{Synthetic CDXs Inspired in Naturally Occurring Xanthones}

Natural compounds have always been a source of inspiration for the discovery of new therapeutic agents [43]. Historically, the first proposed synthesis of a xanthone was achieved by Michael, in 1883, and later by Kostanecki and Nessler, in 1891, through the distillation of O-hydroxy-benzoic acid, acetic anhydride and a phenol [44,45], while the first total synthesis of a naturally occurring xanthone was a euxanthone, described by Ullmann and Panchaud, in 1906 [46]. Several synthetic CDXs analogues of natural xanthones are described. The biological and pharmacological activities evaluated are summarized in Table 1.

\subsubsection{Synthetic Xanthonolignoids}

Xanthonolignoids are a natural class of compounds isolated from plants of the Clusiaceae family (Guttiferae) [47]. They possess a phenylpropane core linked to a xanthone scaffold by a dioxane ring, 
formed by radical oxidative coupling [48,49]. Natural xanthonolignoids include kielcorins, cadensins, subalatin, calophyllumins and gemixanthone [49]. The first xanthonolignoid described was based in 2,3,4-trioxygenated xanthone being isolated, in 1969, from Kielmeyera species [50].

Considering that xanthonolignoids are bioactive molecules and very interesting templates for molecular modifications, several xanthonolignoids were isolated and synthesized [49]. Initially the main goal of their synthesis was to help in the structure elucidation of this class of compounds but subsequently, also to improve their biological and physicochemical properties. Both classic synthesis and biomimetic approaches have been used to obtain xanthonolignoids, mainly kielcorin derivatives [49]. The total synthesis of kielcorin derivatives requires several steps and drastic reaction conditions while the biomimetic way is based on natural building blocks and is achieved by an oxidative coupling of a suitable dihydroxyxanthone and a cinnamyl alcohol derivative, in the presence of an oxidizing agent at room temperature [49].

Pinto et al. [51], in 1987, reported the first biomimetic synthesis of xanthonolignoids of the kielcorin group, specifically kielcorin (1) and its stereoisomer, cis-kielcorin (2) (Figure 1). Both kielcorins $\mathbf{1}$ and 2 were also obtained by a classical method [52,53]. In 1999, by using a biomimetic approach, the synthesis of trans-kielcorin B (3) and trans-isokielcorin B (4) (Figure 1) was described [54].<smiles></smiles><smiles>COc1cc(C2Oc3c(OC)cc4c(=O)c5ccccc5oc4c3OC2CO)ccc1O</smiles><smiles>COc1ccc(C2Oc3cc4oc5ccccc5c(=O)c4cc3OC2CO)cc1O</smiles>
3

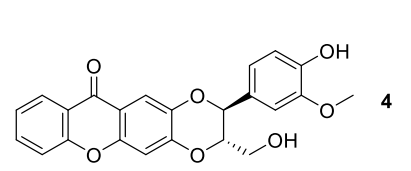<smiles>COc1cc(C2=C(CO)Oc3c(ccc4c(=O)c5ccccc5oc34)O2)ccc1O</smiles><smiles>COc1cc(-c2c(CO)oc3c4c(=O)c5ccccc5oc(oc2=4)=CC=3)ccc1O</smiles><smiles>COc1cc(C2Oc3cc4oc5ccccc5c(=O)c4cc3OC2CO)ccc1O</smiles>

$(2 S, 3 S) 9$

Figure 1. Structures of kielcorin (1) and synthetic derivatives 2-9.

To obtain related bioactive compounds with a kielcorin framework, other constitutional isomers were synthesized by our group, namely trans-kielcorin C (5), trans-kielcorin D (6), trans-isokielcorin $\mathrm{D}$ (7), cis-kielcorin C (8), and trans-kielcorin E (9) [55] (Figure 1). Once again, the synthetic approach, involving an oxidative coupling of coniferyl alcohol with an appropriate xanthone, was modelled on a biomimetic pathway. Different oxidizing agents were used (e.g., $\mathrm{Ag}_{2} \mathrm{O}, \mathrm{Ag}_{2} \mathrm{CO}_{3}$, and $\mathrm{K}_{3}\left[\mathrm{Fe}(\mathrm{CN})_{6}\right]$ ) to investigate the oxidative coupling reactions. The synthesis of trans-kielcorin $\mathrm{C}$ (5) (also designated as demethoxykielcorin) using a classic approach was previously reported by Vishwakarma et al. [53].

Kielcorins 5-9 were evaluated for their in vitro effect on the growth of three human tumor cell lines, MCF-7 (breast), TK-10 (renal), UACC-62 (melanoma), and on the proliferation of human lymphocytes [56]. The growth inhibitory effect was moderate but dose-dependent and influenced by the isomerism of the tested compounds. The trans-kielcorins C (5) and D (6) were the most active. The inhibition of human lymphocyte proliferation induced by phytohemagglutinin (PHA) was detected [56]. The high potency and selectivity observed for these compounds suggested that kielcorins may be an important model for developing potent and isoform-selective protein kinase C (PKC) inhibitors [31]. Accordingly, kielcorins 5-9 revealed an effect compatible with PKC inhibition similar to that exhibited by the well-established PKC inhibitor chelerythrine [57]. The trans-kielcorins C (5) and 
E (9) were evaluated and demonstrated protectives effects against tert-butylhydroperoxide-induced toxicity in freshly isolated rat hepatocytes [58].

In order to study if the growth inhibitory effects of the kielcorins 5-9 depended on the stereochemistry, analytical LC methods using four carbamates of polysaccharide derivative CSPs and multimodal elution conditions were developed for their enantioresolution [59]. An amylose tris-3,5-dimethylphenylcarbamate CSP was chosen for a preparative resolution scale-up considering not only the highest enantioselectivity obtained for these chiral compounds, but also due to its low retention factors [59]. Consequently, the enantiomers of the kielcolins 5-7 and $\mathbf{9}$ were efficiently separated by chiral LC on a multimilligram scale. A solid-phase injection system was developed and combined with a closed loop recycling system to increase the productivity and recovery of the preparative process [60]. The enantiomeric purity was also measured being higher than $99 \%$ for each enantiomer, except for compound 5 [60].

The inhibitory activity of the racemates 5-7 and 9 as well as of the corresponding enantiomers on in vitro growth of the human breast adenocarcinoma cell line MCF-7 was evaluated and compared. The most evident enantioselectivity was noticed between the racemate of trans-kielcorin $\mathrm{D}$ (6) (inactive) and the active enantiomers (+)-6 and (-)-6 [60].

\subsubsection{Derivatives of Psorospermin}

Psorospermin (10) was isolated from the bark and roots of the African plant Psorospermum febrifugum, in 1980 [61,62]. It is a natural fused tetracyclic xanthone containing two stereogenic centers with $\left(2 R, 3^{\prime} R\right)$-stereochemistry and a reactive epoxide (Figure 2$)$. The importance of the configuration and the functionality of the epoxydihydrofuran group for the in vivo activity have been evaluated [31,50]. The total synthesis of psorospermin (10) was reported for the first time in 2005, by obtaining the xanthone skeleton by the method of Grover et al. [62], including thirteen steps and with an overall yield of $1.7 \%$. Psorospermin (10) revealed interesting biological activities showing antileukaemic, and antitumor activity in several human cell lines [31,62].

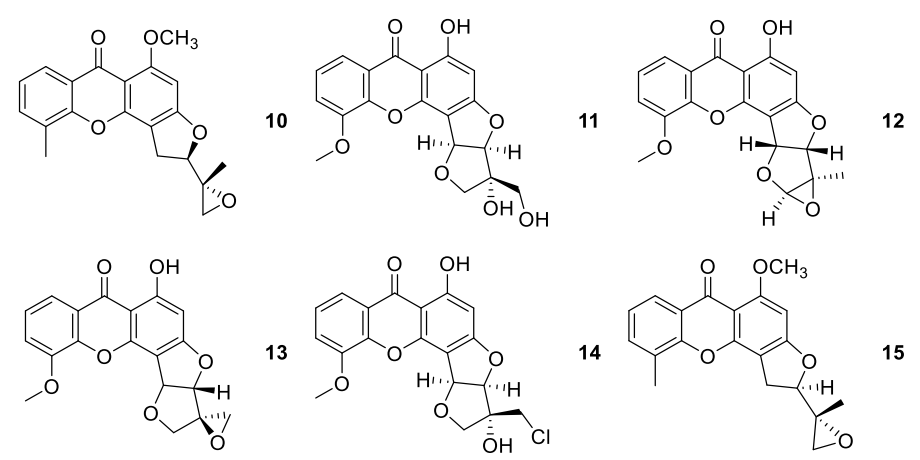

Figure 2. Structures of psorospermin (10) and synthetic derivatives 11-15.

Additionally, the $(R, R)$-stereochemistry of psorospermin (10) gave optimum DNA alkylation and antitumor activity, although all four possible stereoisomers show topoisomerase II-dependent alkylation [63].

Two ring-constrained derivatives of psorospermin were also synthesized, namely, stereoisomer 12, a ring-constrained ( $2 R, 3 R)$-form, and 13, a ring-constrained (2R,3S)-compound (Figure 2) [63]. The chlorohydrin 14 retains psorospermin-like DNA alkylation characteristics despite its rigid structure and high affinity for DNA. The chlorohydrin $\mathbf{1 4}$ and epoxide $\mathbf{1 3}$ showed increased cytotoxicity against a range number of human tumor cell lines, compared to isohydroxypsorofebrin (11) [63].

Another study described the synthesis of two diastereisomeric pairs of O-5-methyl psorospermin and evaluation of in vitro activity against a range of solid and hematopoietic tumors. The diastereisomeric pair having the naturally occurring enantiomer $(2 R, 3 R)(15)$ (Figure 2) was the most active across all the cell lines tested. In subsequent studies using the four isomers of $O-5$-methyl 
psorospermin, the order of biological potency was $(2 R, 3 R)>(2 R, 3 S)=(2 S, 3 R)>(2 S, 3 S)$ [64]. The compound $(2 R, 3 R)$ psorospermin (15) showed to be as effective as gemcitabine (chemotherapeutic drug) in slowing tumor growth in vivo in pancreatic cancer model [64].

\subsubsection{Derivatives of Muchimangins}

In many tribes and folk medicine use, plants and other organisms are commonly used to treat several conditions. For example, in Africa, the roots of Securidaca longepedunculata are used to treat sneezing, syphilis, gonorrhea, rheumatic pain, headache, feverish pain, malaria, sleeping sickness, among other conditions [65]. Muchimangins are a minor constituent of this specie and their biological activities have not been fully explored [66]. Dibwe et al. [67] reported the promising antiausteric activity of one natural occurring muchimangin against human pancreatic cancer PANC-1 cell line. Besides the anticancer promising activity, Kodama et al. [66] explored the antimicrobial activity of these structures and performed SAR studies. Accordingly, they synthesized several muchimangins derivatives 16-20 (Figure 3), and analyzed their antimicrobial activity.<smiles>[R]c1cc([R])c2c(=O)c3ccc([R])c([C@H](c4ccccc4)c4cc(OC)c(OC)c(OC)c4)c3oc2c1</smiles>

$\begin{array}{cccccccccccc}\mathrm{R}_{1} & \mathrm{R}_{2} & \mathrm{R}_{3} & & \mathrm{R}_{1} & \mathrm{R}_{2} & \mathrm{R}_{3} & & \mathrm{R}_{1} & \mathrm{R}_{2} & \mathrm{R}_{3} & \\ \mathrm{OH} & \mathrm{OH} & \mathrm{OH} & \begin{array}{r}16 \\ (+)-16 \\ (-)-16\end{array} & \mathrm{OH} & \mathrm{H} & \mathrm{OH} & \begin{array}{r}17 \\ (+)-17 \\ (-)-17\end{array} & \mathrm{H} & \mathrm{H} & \mathrm{OH} & \begin{array}{r}1+(+)-18 \\ (-)-18\end{array} \\ \mathrm{OCH}_{3} & \mathrm{OCH}_{3} & \mathrm{OH} & 19 & \mathrm{OCH}_{3} & \mathrm{OCH}_{3} & \mathrm{OCH}_{3} & 20 & & & & \\ & & & & & & & & & & \end{array}$

Figure 3. Structures of muchimangin derivatives 16-20.

To synthesize the muchimangins derivatives 16-20, they etherified commercially available 1,2,4-trihydroxybenzene with dimethyl sulfate, producing 1,2,4-trimethoxybenzene. Then, by acylation 2,4,5-trimethoxybenzophenone was obtained. This compound was further reduced to afford 2,4,5-trimethoxydiphenylmethanol, part of the muchimangin skeleton. Afterwards, the corresponding xanthone moiety was obtained using Eaton's reagent. To finalize, both structural moieties were coupled by a Bronsted acid-catalyzed nucleophilic substitution, to produce the corresponding racemates [66]. In order to clarify the effect of chirality, Kodama et al. [66] separated the most promising derivatives using a CSP and to identify their optical rotation via polarimetry.

The preliminary SAR studies suggested that the presence of a hydroxyl group at C-6 was important for the antibacterial activity. Moreover, enantioselectivity occurred for compound 18, with the dextro (+) enantiomer being more active against $S$. aureus than the levo (-) enantiomer and the racemate [66].

\subsubsection{Derivatives of Mangiferin}

Mangiferin (21, Figure 4) is a natural occurring chiral xanthone with a large spectrum of biological activities, which have been explored for many years [68-71]. Several authors have compiled information about the biological properties of mangiferin and derivatives [72,73].

As previously reported by Araújo et al. [74], mangiferin derivatives present a large spectrum of antimicrobial activities. Singh et al. [75,76] developed new mangiferin derivatives 22-27 (Figure 4) and screened their antipyretic and antimicrobial activities. The synthetic strategy used equivalent molar proportions of mangiferin and an appropriate base ( $R$-aromatic amine) at reflux to give the corresponding derivative. 


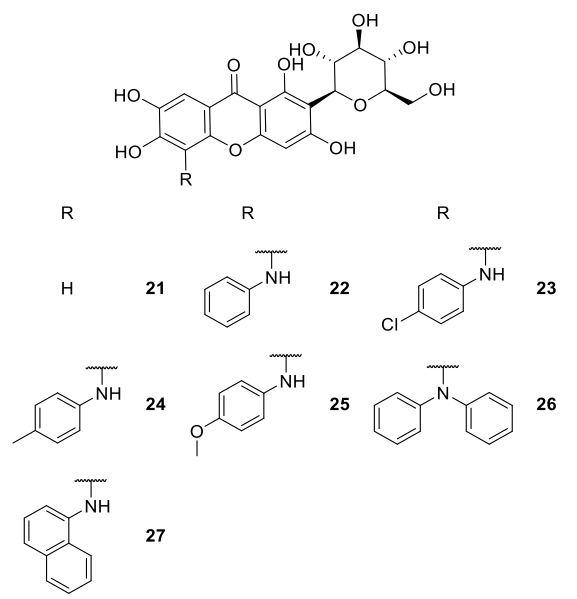

Figure 4. Structures of mangiferin (21) and some synthetic derivatives 22-27 with antipyretic and antimicrobial activities.

According to the results, it was suggested that the antipyretic activity may be attributed to the anti-inflammatory and antioxidant potential of mangiferin and its derivatives [76]. However, further investigations are required to understand the mechanism of action to prove its antipyretic activity. Regarding to the antimicrobial activity, the same compounds showed powerful inhibition of the growth of S. virchow and significant antibacterial activity against B. pumilus and B. cereus. On the other hand, all tested compounds revealed poor growth inhibition of $P$. aeruginosa and low antifungal activity [75].

In other studies, the analgesic, antioxidant and anti-inflammatory activities of other mangiferin derivatives 28-34 (Figure 5) were explored [77,78]. Dar et al. [77] analyzed the analgesic and antioxidant activities of acetylated (28), methylated (29), and cinnamoylated (30) mangiferin, where compound 12 was acetylated to afford 14. Mahendran et al. [78] observed the analgesic and anti-inflammatory activities of mangiferin with benzoyl (31), benzyl (32), and acetyl (33) groups.

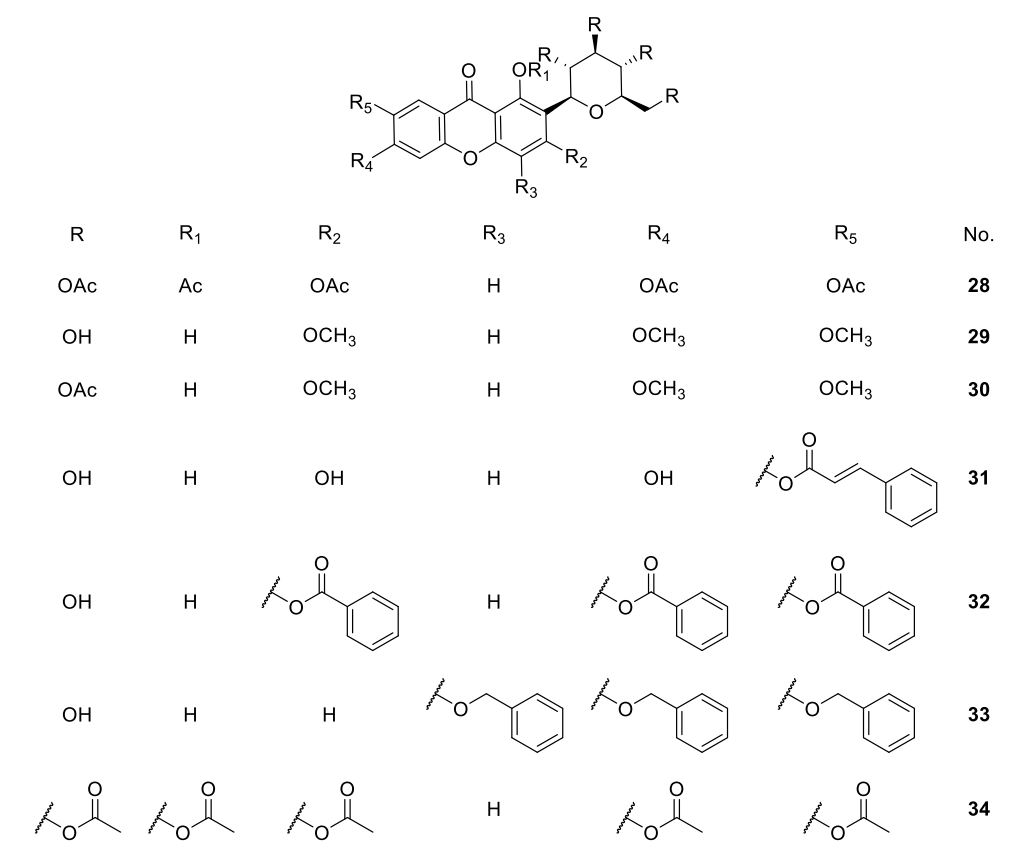

Figure 5. Structures of mangiferin derivatives 28-34 with antioxidant, anti-inflammatory and analgesic activities.

The results demonstrated that mangiferin derivatives substituted with benzoyl (compound 32) and acetyl (compound 34) groups displayed better antioxidant activity than mangiferin (21) in lipid 
peroxidation, p-NDA, deoxyribose and alkaline DMSO assays, while neither compound had analgesic nor anti-inflammatory activities. In all of these methods, standard drugs showed better activity than mangiferin and its derivatives 28-34 [78].

Mangiferin (21) is also known to possess antidiabetic activity $[79,80]$. This biological activity was further investigated for other mangiferin derivatives $\mathbf{3 5 - 4 2}$ and $\mathbf{4 6 - 5 3}$, by Hu et al. [81,82] and $\mathbf{4 3 - 4 5}$ by Li et al. [83] (Figure 6). These works evaluated the properties of mangiferin derivatives as protein tyrosine phosphatase 1B (PTP1B) inhibitors in order to demonstrate their hypoglycaemic activity. The PTP1B has an important role in type 2 diabetes and obesity [84], which is primarily responsible for the dephosphorylation of the activated insulin receptor and thus downregulates insulin signalling [85]. For this reason, PTP1B inhibitors are a good strategy for diabetes mellitus treatment.

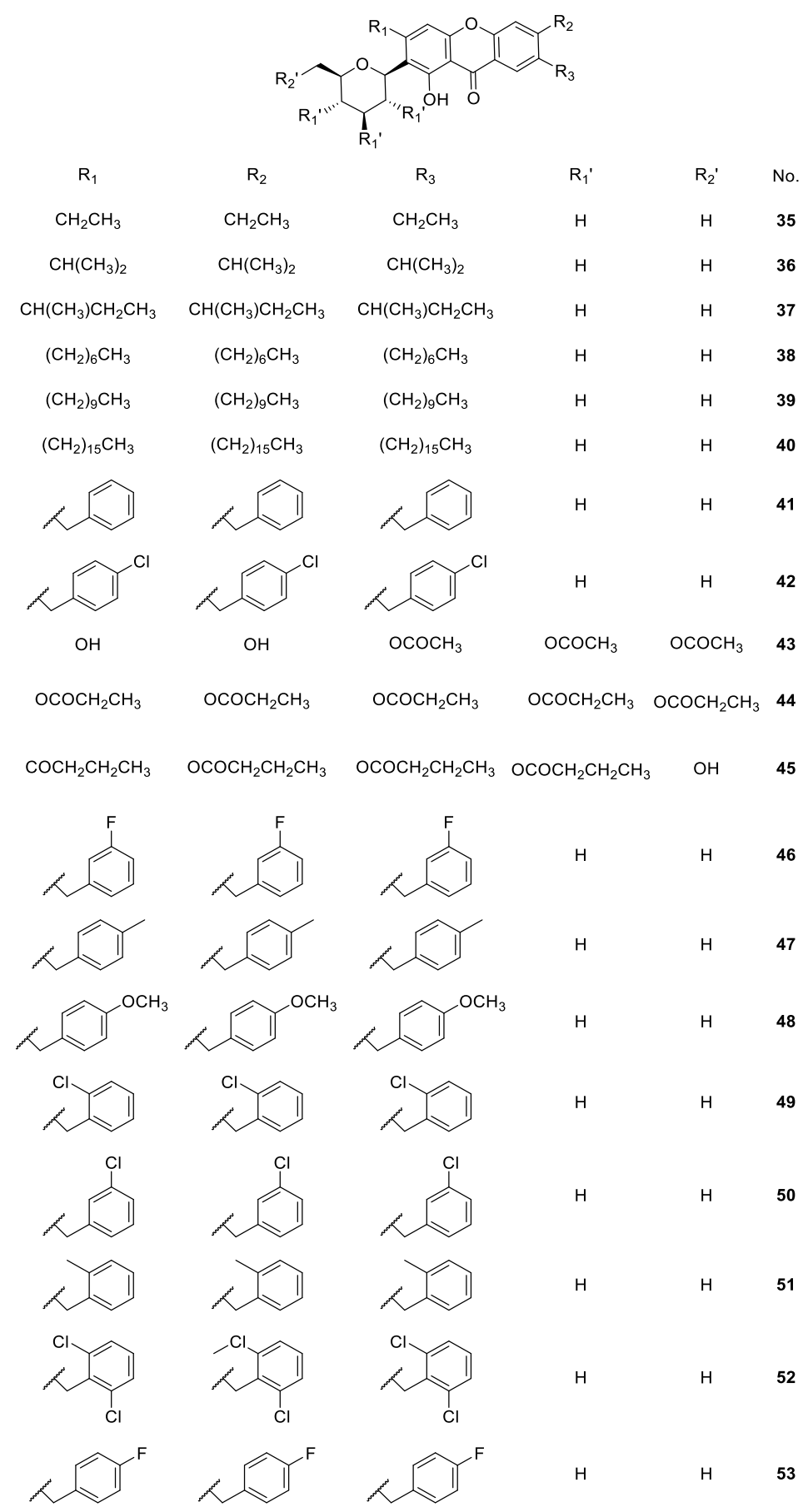

Figure 6. Structures of mangiferin derivatives 35-53 with antidiabetic activity. 
According to Hu et al. [81,82], mangiferin (21) is a weak PTP1B inhibitor, whereas some derivatives such as 36, 38 and 39 showed good inhibition of this protein. The SAR studies suggested that the substitution of free hydroxyl at C-3, C-6, C-7 of mangiferin (21) remarkably enhanced the inhibition, and the mono- or dichloro benzylated derivatives displayed better inhibitory activity than other groups [81,82]. However, further modification and biological studies are still in progress [81].

Li et al. [83] also demonstrated that the esterified-derivatives of mangiferin 43-45 (Figure 6) could repair damaged islet cells, and had higher lipid-solubility, and more potent hypoglycaemic activity than the mangiferin (21). The SAR studies indicated that the larger the esterification moieties or the higher lipid-solubility, the more potent hypoglycaemic activity was displayed by the derivative. Thus, esterification proved to be an effective way to improve the activity of mangiferin as a potential antidiabetic drug [83].

Correia-da-Silva et al. [86] developed new sulfated xanthones 54-57, inspired by the mangiferin scaffold, to study their anticoagulant and antiplatelet properties (Figure 7). The synthetic approach included the sulfation of commercially available mangiferin affording mangiferin- $2^{\prime}, 3^{\prime}, 4^{\prime}, 6^{\prime}-$ tetrasulfate. It was found that an increase of the quantities of sulfating agent furnished the $2^{\prime}, 3$, $3^{\prime}, 4^{\prime}, 6,6^{\prime}, 7$-heptasulfated derivative. The precursor of the other derivatives could be a suitable xanthone scaffold, where 3,6-(O- $\beta$-glucopyranosyl)xanthone was obtained after deprotection of the glycosylated xanthone 3,6-(2,3,4,6-tetra-O-acetyl- $\beta$-D-glucopyranosyl)xanthone. The sulfation of 3,6-dihydroxyxanthone allowed preparation of persulfated 3,6-(O- $\beta$-glucopyranosyl)xanthone. Two polysulfated xanthonosides proved to be inhibitors of thrombosis, combining anticoagulant and antiplatelet effects in a single molecule [86].

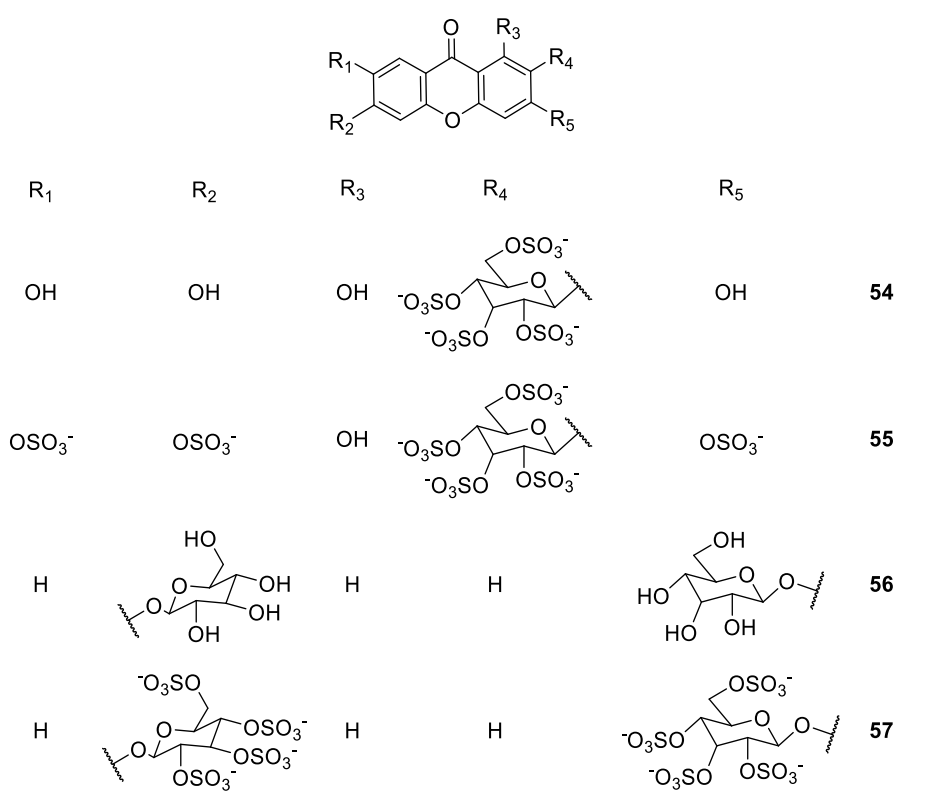

Figure 7. Structures of mangiferin derivatives 54-57 with anticoagulant and antiplatelet activities.

\subsubsection{Derivatives of $\alpha$-Mangostin}

One of the most studied xanthones found in Nature is $\alpha$-mangostin, isolated from tropical fruits of Garcinia mangostana which have been used for centuries in folk medicine to treat many conditions $[87,88]$. Several studies have reported its anticancer and antimicrobial activities, among others, which have prompted researchers all over the world to synthesize diverse derivatives [74,87-94].

One strategy concerned cationic antimicrobial peptides (CAMPs), amphipathic structures whose hydrophobic moiety penetrates the membrane core, while the cationic residues disrupt bacterial membranes [95-98]. Due to the manufacturing costs and poor stability of peptides, Koh et al. [95,99] developed small-molecules 58-70 with CAMP characteristics by combining the $\alpha$-mangostin core with 
basic amino acids moieties (Figure 8). The purpose of the work was to confirm if lipophilic chains enhance the membrane permeability and to examine the role of the cationic moieties conjugating the xanthone scaffold with basic amino acids [99]. This strategy was also used to develop new anti-mycobacterial derivatives 65-70 [95], and by Lin et al. [97] for studies seeking new antimicrobial and hemolytic compounds.

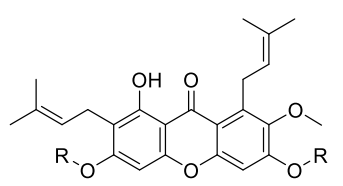

$\mathrm{R}$<smiles>CCCC(=O)N[C@@H](CCCCN)C(=O)OC</smiles>

58

61<smiles>CCCC(=O)N[C@@H](CCCNC(=N)N)C(=O)ON</smiles><smiles>CCCC(=O)N[C@@H](Cc1c[nH]cn1)C(=O)OC</smiles><smiles>CC(C)(C)CNCCCN</smiles>

65<smiles>CC(C)CCNCCNC(=N)N</smiles><smiles>CCCN(CCC)CC(C)(O)C(C)(C)C</smiles>

68<smiles>CCN(CC)CC(O)C(C)C</smiles>

70

$\mathrm{R}$<smiles>CCCC(=O)N[C@@H](CCCNC(=N)N)C(=O)OC</smiles>

62<smiles>CC(C)CC(=O)N[C@@H](CCCNC(=N)N)C(=O)OC(C)(C)C</smiles><smiles>CCCC(O)CNC(CO)(CO)CO</smiles>

Figure 8. Structures of derivatives of $\alpha$-mangostin 58-70.

According to the results, the amphiphilic xanthone derivatives 65-70 (Figure 8) possessed promising mycobacterial activity without resistance mechanisms, which may contribute to the development of an entirely new class of therapeutics for tuberculosis [95]. Besides the interesting activity of these compounds, the cationic and hydrophobic moieties enhanced the water-solubility, and also lead to high membrane selectivity and excellent antibacterial activity against Gram-positive bacterial strains, including methicillin-resistant Staphylococcus aureaus and vancomycin-resistant Enterococcus. It is important to point out that the membrane selectivity of these compounds was higher than several membrane-active antimicrobial agents in clinical trials $[97,99]$.

\subsubsection{Derivatives of Caged Xanthones}

The Garcinia genus contains caged xanthones which mainly occur in a few species like G. morella, G. hanburyi, G. bracteata, G. gaudichaudii, and G. scortechinii, widely distributed in Southeast Asia [100-103]. The caged core is responsible for the vast range of bioactivities of this class of compounds, such as anti-viral, and antibacterial effects, among others [104-107]. Many reports have described the potential antitumor activity of gambogic and morrelic acids [100,101,104,105,107,108]. According to this, many caged xanthones 71-155 have been synthesized and studied through the last years, with a diversity of purposes (Figures 9-14). 


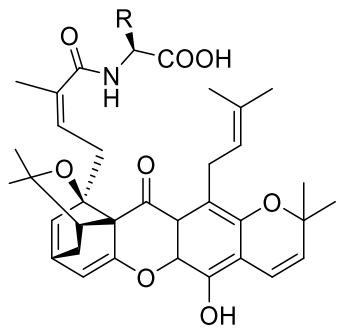

$\begin{array}{cccccccc}\mathrm{R} & \text { No. } & \mathrm{R} & \mathrm{No} . & \mathrm{R} & \text { No. } & \mathrm{R} & \text { No. } \\ \mathrm{CH}\left(\mathrm{CH}_{3}\right)_{2} & 71 & \mathrm{CH}_{2}\left(\mathrm{C}_{6} \mathrm{H}_{5}\right) & 72 & \mathrm{CH}_{2} \mathrm{CH}_{2} \mathrm{COOBz} & 73 & \mathrm{CH}_{2} \mathrm{CH}_{2} \mathrm{COOH} & 74 \\ \mathrm{CH}_{2} \mathrm{CH}_{2} \mathrm{SCH}_{3} & 75 & \mathrm{CH}_{2} \mathrm{CH}\left(\mathrm{CH}_{3}\right)_{2} & 76 & \mathrm{CH}_{2} \mathrm{OH} & 77 & \mathrm{CH}\left(\mathrm{CH}_{3}\right) \mathrm{CH}_{2} \mathrm{CH}_{3} & 78 \\ & & & & & & & \\ & 79 & \mathrm{CH}_{2} \mathrm{CH}_{2} \mathrm{CONTrt} & 80 & \mathrm{CH}_{2} \mathrm{CH}_{2} \mathrm{CONH}_{2} & 81 & \left(\mathrm{CH}_{2}\right)_{4} \mathrm{NH}_{2} & 82\end{array}$

Figure 9. Structures of caged xanthones 71-82 with antimicrobial activity.

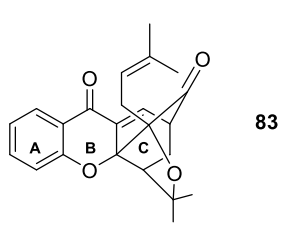

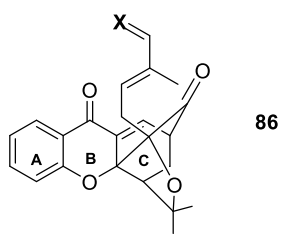

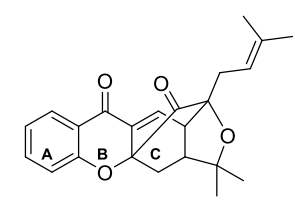

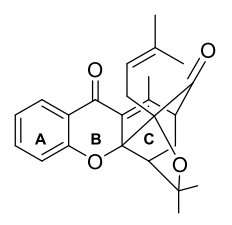

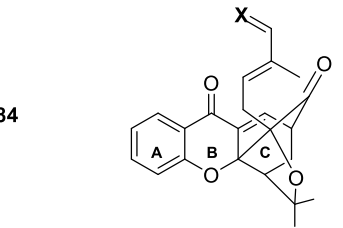

87

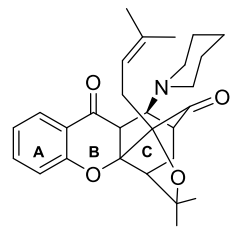

$R$<smiles>CCCCNC(=O)CCCCC1SCC2NC(=O)NC21</smiles>

$91 \mathrm{R}$ :<smiles></smiles>

92<smiles>[R]CCCNC(=O)CCC1=N/C(=C/C2=C(C)CC(C)C2[NH3+])C=C1</smiles>

Figure 10. Structures of caged xanthone 83-96, with antimalarial and antitumor activities. 


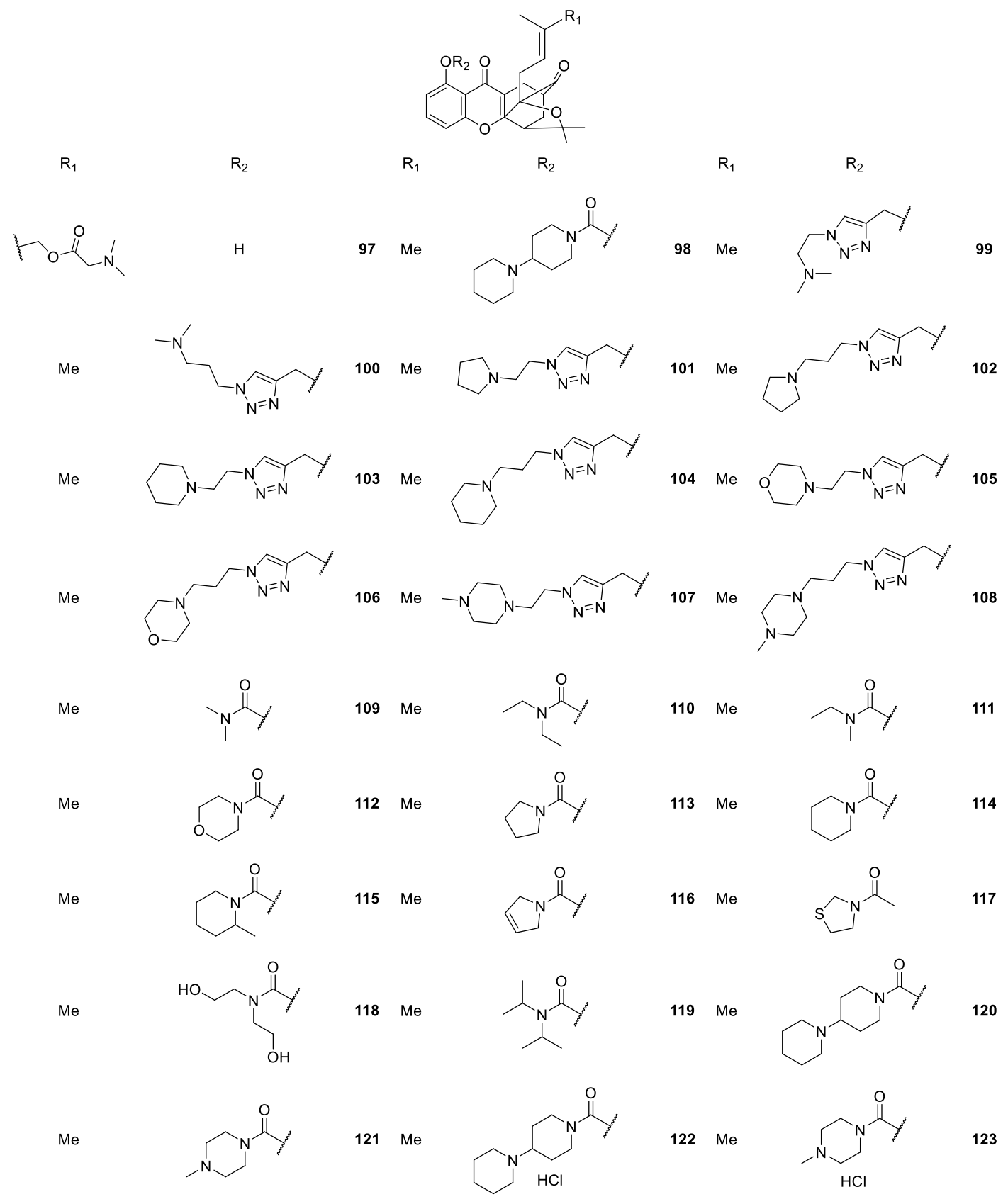

Figure 11. Structures of caged xanthones 97-123, with antitumor activity. 


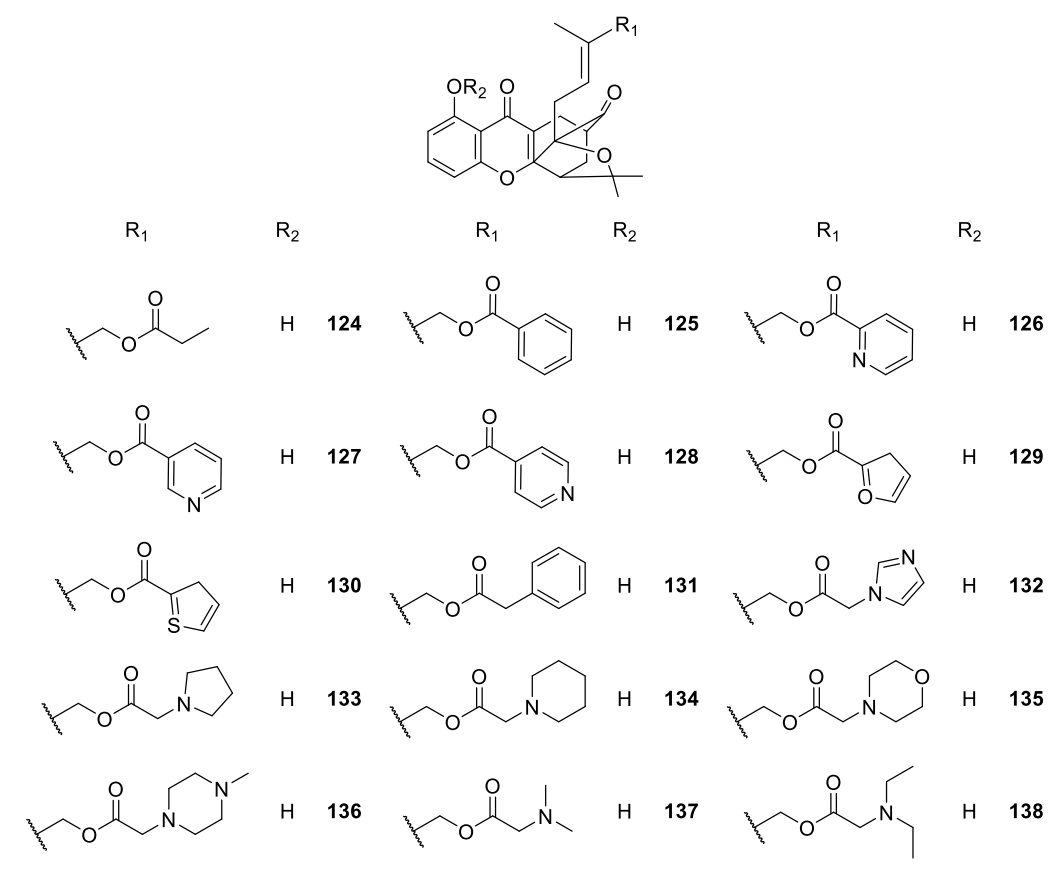

Figure 12. Structures of caged xanthones 124-138, with antitumor activity.

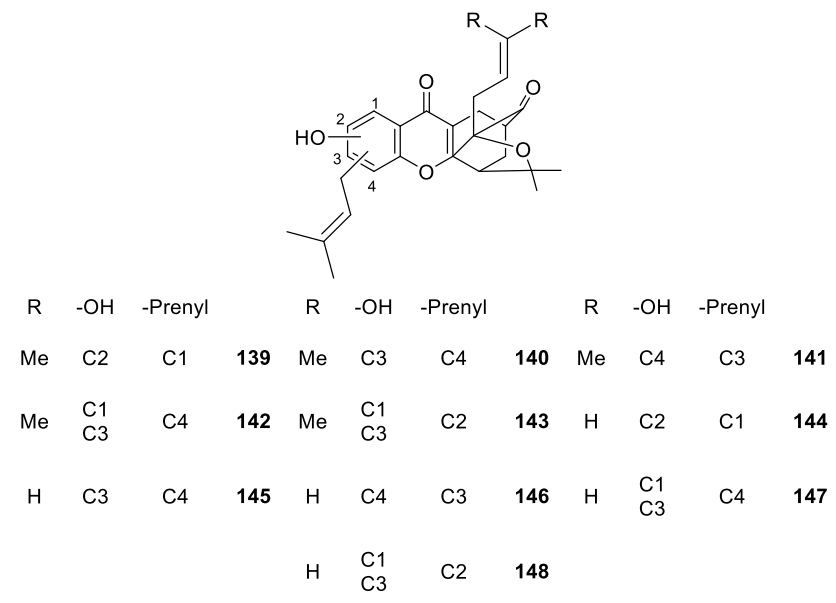

Figure 13. Structures of caged xanthones 139-148, with antitumor activity.

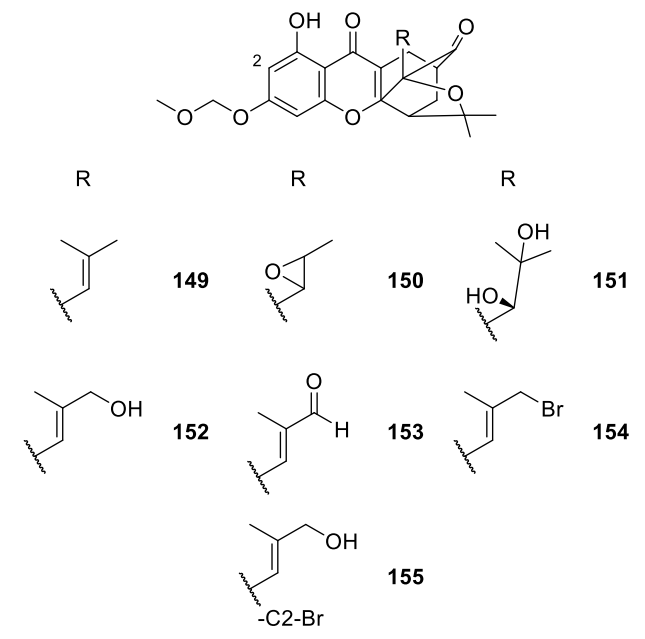

Figure 14. Structures of gambogic acid derivatives 149-155, with antitumoral activity. 
Chaiyakunvat et al. [105] inspired by the biological properties of caged xanthones, synthesized a few morrelic acid derivatives and evaluated their antimicrobial activity. They started with the synthesis of methylated morrellic acid and, afterwards, they synthesized derivatives 71-82 with amino acid moieties via solid-phase synthesis (Figure 9).

The morellic acid derivatives showing more inhibition of bacterial growth were the ones with an amino acid-containing hydrophobic side chain like 71, 72, 76, 78 and 79 (Figure 9) [105]. This is in agreement with previous reports where the antimicrobial activity was higher in the structures with hydrophobic and/or aromatic amino acids [99,105].

Theodorakis et al. [106,109-111] synthesized new caged xanthones and studied their properties. They developed a Claisen/Diels-Alder reaction cascade that, in combination with a $\operatorname{Pd}(0)$-catalyzed reverse prenylation, provided a rapid and efficient access to the caged xanthone pharmacophore. Afterwards, various A-ring oxygenated derivatives of cluvenone (83) were further synthesized and analyzed (Figure 10) [106,109-111].

The SAR studies showed that their activity could be substantially improved by attaching a triphenylphosphonium group at the A ring of the caged xanthone. Derivatives 93 and 94 (Figure 10) were found to be highly effective as antimalarials against Plasmodium falciparum [106]. The conjugation of these compounds with a phosphonium salt improved their efficacy, resulting in lead compounds with a promising therapeutic window [106]. It was suggested that, further modification of the caged xanthone could increase the selective cytotoxicity and lead to a promising lead candidate [106].

Cluvenone (83) was also reported to induce cell death via apoptosis, presenting similar cytotoxicity in multidrug-resistant and sensitive leukemia cells $[109,110]$. The caged xanthone derivatives proved to be active with cytotoxicity at low to sub-micromolar concentrations in solid and non-solid tumor cell lines, respectively. Additionally, they induced apoptosis in HUVE cells. Remarkably, similar $\mathrm{IC}_{50}$ values were obtained for the compounds tested in the HL-60 and HL-60/ ADR cell lines, suggesting that these compounds were not subject to a drug resistance mechanism. Therefore, it was suggested that members of this family of compounds may have therapeutic potential in relapsed cancers typically resistant to standard chemotherapeutic agents. In addition, the cytotoxicity observed in HUVE cells suggested that these compounds may be interesting leads for the development of new angiogenesis inhibitors [111]. Elbel et al. [112] synthesized selected A-ring hydroxylated analogues and evaluated their effect on cell growth, mitochondrial fragmentation, mitochondriotoxicity and Hsp90 client protein degradation. They found out that both the C6 and C18 hydroxylated cluvenones inhibited the growth of CEM cells at low micromolar concentrations and induced cell death via the mitochondrial pathway. In addition, cluvenone (83) and the hydroxylated cluvenones induced Hsp90-dependent protein client degradation at low micromolar concentrations [112].

Table 1. Summary of the biological activities of synthetic CDXs inspired in natural xanthones.

\begin{tabular}{ccc}
\hline CDXs & Biological Activities & Ref. \\
\hline Kielcorin derivatives 2-9 & $\begin{array}{c}\text { Antitumor and protein kinase C } \\
\text { inhibition }\end{array}$ & {$[56,58,59,61]$} \\
\hline Psorospermin derivatives 11-15 & Antitumor & {$[64]$} \\
\hline Muchimangin derivatives 16-20 & Antimicrobial & {$[66]$} \\
\hline Mangiferin derivatives 21-57 & $\begin{array}{c}\text { Antipyretic, antimicrobial, } \\
\text { analgesic, antioxidant, } \\
\text { anti-inflammatory, antidiabetic, } \\
\text { anticoagulant and antiplatelet }\end{array}$ & {$[68,72,73,75-78,81-83,86]$} \\
\hline --Mangostin derivatives 58-70 & $\begin{array}{c}\text { Antimicrobial, hemolytic and } \\
\text { antimycobacterial }\end{array}$ & {$[91,95-99,118]$} \\
\hline Caged xanthones 71-155 & $\begin{array}{c}\text { Antimalarial, antitumor, } \\
\text { anti-proliferation and } \\
\text { anti-angiogenesis }\end{array}$ & {$[106,108,109,111,113-117,119,120]$} \\
\hline
\end{tabular}


Zhang et al. [113-116] synthesized a series of caged xanthone derivatives to improve the physicochemical properties and in vivo cytotoxic potency. For that, they relied on MAD28 synthesis and characterization of the derivatives. The structural modifications revealed that the presence of a carbamate moiety was useful for obtaining comparable cytotoxicity and improved aqueous solubility and permeability (Figure 11).

It is important to highlight that compound 137 (named DDO-6306, Figure 12) displays growth inhibition in Heps transplanted mice, and is now undergoing further evaluation as a candidate for cancer chemotherapy [115]. In a more recent study, compound 105 (Figure 11), considered as the lead compound and called MAD28, successfully led to the discovery of a novel series of natural-product-like triazole-bearing caged xanthones with improved drug-like properties as orally-active antitumor agents in vivo [115].

Regarding the caged xanthone derivatives containing carbamate scaffolds 109-123 (Figure 11), the results showed a potent antiproliferative activity and good physicochemical properties, which contributed to improving their in vivo activities. The compound 122 (DDO-6337) showed moderate inhibitory activity toward Hsp90 ATPase and resulted in the degradation of Hsp90 client proteins, such as HIF-1, which ultimately contributed to its antitumor and anti-angiogenesis activities [116].

Compounds 140-143 (Figure 13) exhibited micromolar inhibition against several cancer cell lines. Some interesting SAR considerations have been highlighted, such as the importance of the periphery gem-dimethyl groups in maintaining the anti-tumor activity, the effect of the substituent at C-1 position of B-ring on activity, since hydroxyl group at C-1 position enhanced the potency while prenyl group reduces it, and, that the change of hydroxyl or prenyl groups in carbons C-2, C-3 and C-4 had no significant effect on the anti-tumor activity. These events indicated that referred sites can be used to improve drug-like properties [114].

In another study, Miao et al. [117] developed small molecule entities inspired by the structure of gambogic acid. They focused on modifications of the prenyl moiety of the caged xanthones which led to synthesize seven derivatives 149-155 (Figure 14), which were tested for anti-tumor activity [117].

The SAR studies suggested that compounds 151, 153, and 154 showed similar cytotoxicity to gambogic acid against A549 cells, whereas compounds 149-151 and 152 were less active than gambogic acid. Although these experiments were preliminary, the results suggested that promising agents with anti-tumor activities could be obtained by modification at C-2 position of the B ring and at C-21/22 or C-23 position of the prenyl group in the caged scaffold. The formation of dihydroxy and epoxy groups of the double bond at C-21/22 and the introduction of an electron-withdrawing group at C-23 evidently affected the anti-proliferation activity [117]. In Table 1 a summary of the synthetic CDXs inspired in natural xanthones and their described biological activities are presented, as well as the associated references.

\subsection{Synthetic CDXs Obtained by Binding/Coupling Chiral Moieties to the Xanthone Scaffold}

Another approach to acquire synthetic CDXs is by binding chiral moieties to the xanthone scaffold using different strategies. The biological and pharmacological activities evaluated of the various CDXs obtained by this strategy are included in Table 2 .

\subsubsection{XAA and DMXAA Analogues}

DMXAA (5,6-dimethylxanthone-4-acetic acid, vadimezan, ASA404, 157, Figure 15) is a simple carboxylated xanthone discovered by SAR studies involving a series of xanthone-4-acetic acids (XAA, 156, Figure 15) related to the parent compound flavone acetic acid [121]. DMXAA is one of the most studied xanthones considering not only its remarkable pharmacological profile [122-131], but also its physicochemical and pharmacokinetic properties $[130,132,133]$. It is a tumor vascular-disrupting agent leading to a fast, vascular collapse and tumor necrosis by immunomodulation and cytokines induction. DMXAA (157) also demonstrated antiviral [134], antiplatelet and antithrombotic [135] activities. This synthetic xanthone is not chiral but, it is evident that structurally and from a biological 
activity perspective, it may be an attractive scaffold for the development of other bioactive analogues and derivatives.<smiles>O=C(O)Cc1cccc2c(=O)c3ccccc3oc12</smiles>

156<smiles>Cc1ccc2c(=O)c3cccc(CC(=O)O)c3oc2c1C</smiles>

157<smiles>Cc1cccc2c(=O)c3cccc(C(C)C(=O)O)c3oc12</smiles>

159<smiles>Cc1ccc2oc3cc(OC(=O)C(C)O)ccc3c(=O)c2c1</smiles>

163

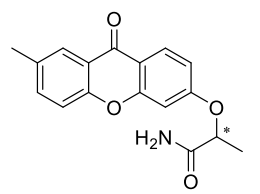

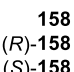

161

164

Figure 15. Structures of XAA (156), DMXAA (157) and chiral analogues 158-164.

Rewcastle et al. [136], in 1991, synthetized the DMXAA chiral analogues 2-(5-methyl-9-oxo-9Hxanthen-4-yl)propanoic acid (158) and 2-(9-oxo-9H-xanthen-4-yl)propanoic acid (159) as racemates (Figure 15). CDX 159 was synthetized via bromination of 4-ethylxanthenone followed by conversion of the resulting 4-(1-bromoethyl)xanthenone to compound 159 via the nitrile. CDX 158 was obtained by reaction of $2^{\prime}$-hydroxyacetophenone with benzyl chloride under phase-transfer conditions, giving 2'-benzyloxyacetophenone, which was converted successively to an alcohol, using $\mathrm{NaBH}_{4}$, and a chloride, with anhydrous $\mathrm{CaCl}_{2}$ and $\mathrm{HCl}$. After three reaction steps, 2-(2-hydroxyphenyl)propanoic acid was obtained and then reacted with 2-iodo-3-methylbenzoic acid via a copper/TDA-catalysed condensation. Finally, the resulting diacid was ring-closed using $\mathrm{H}_{2} \mathrm{SO}_{4}$ to give the racemic compound 158. For this CDX both enantiomers were separated by indirect method employing $(R)-(-)$-pantolactone as chiral resolving agent. The obtained mixture of diastereomers was separated by chromatography on silica gel. Further, hydrolysis of the esters under non-enolizing conditions afforded both enantiomers, (S)-(+)-158 and $(R)-(-)-\mathbf{1 5 8}$ (Figure 15) [136].

The racemic compounds 158 and 159, as well as enantiomers (S)-(+)-158 and $(R)-(-)-158$ were tested in in vitro and in vivo tumor assays [136]. It was found that all the compounds were active. Moreover, enantioselectivity was observed, being the $S$-(+)-enantiomer much more dose-dependent than the $R$-(-)-enantiomer. It was suggested that the enantiomers have different intrinsic activities, rather than differing in their metabolism [136]. CDX 159 had been tested previously as anti-inflammatory agent [137].

Marona et al. reported the synthesis [138] of three new chiral analogues of XAA 160-162 (Figure 15) and the evaluation of their cytotoxicity against J7774A.1 cells [139]. Compounds $\mathbf{1 6 0}$ and $\mathbf{1 6 1}$ were obtained by condensation of 2-hydroxyxanthone and 2-methyl-6-hydroxyxanthone, respectively, with $\alpha$-bromopropionic acid and compound 162 by esterification of compound 161 [138]. Regarding the biological activity tested, it was found that all CDXs showed weak cytotoxicity [139].

Recently, Zelaszczyk et al. [140] synthesized two new chiral XAA derivatives $\mathbf{1 6 3}$ and 164 (Figure 15) by the reaction of 3-hydroxyxanthone with ethyl 2-bromopropanoate, followed by ester hydrolysis [140]. These compounds were found to have anti-inflammatory and analgesic activities [34,140].

\subsubsection{Synthetic Aminoalkanolic CDXs}

Our group has a vast experience in synthesis and biological/pharmacological activity evaluation of xanthone derivatives [86,141-147] and, recently, reported the synthesis of a library of CDXs 165-179 
in an enantiomerically pure form (Figures 16 and 17) [148,149]. Among the synthesized CDXs, the compounds 166-171 and 174-179 are aminoalkanolic, while CDXs 165, 172 and 173 comprise of simple amines with a $p$-tolyl moiety (compounds 165 and 173) or an aminoester (compound 172) [148,149].<smiles>COc1ccc2c(=O)c3cc(C(=O)O)ccc3oc2c1</smiles>

$\mathrm{R}$<smiles></smiles>

(R)-165 $(S)-165$<smiles>CCNC(=CCO)C(C)C</smiles>

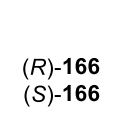<smiles>CC=C(CC(C)C)NCC</smiles>
(S)-167

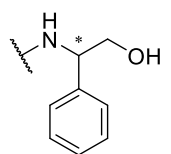<smiles>[124In]</smiles>
$(R)-168$
$(S)-168$<smiles>CCC(C)=NC(C)=CO</smiles>
$(R)-169$
$(S)-169$<smiles>CCNCC(C)O</smiles>
$(R)-170$
$(S)-170$<smiles>CCNC(=O)C(O)c1ccccc1</smiles><smiles>CCNC(C)C(=O)OC(C)(C)C</smiles>

$(R)-172$

Figure 16. Structures of aminoalkanolic CDXs 166-171 and analogues 165 and 172.

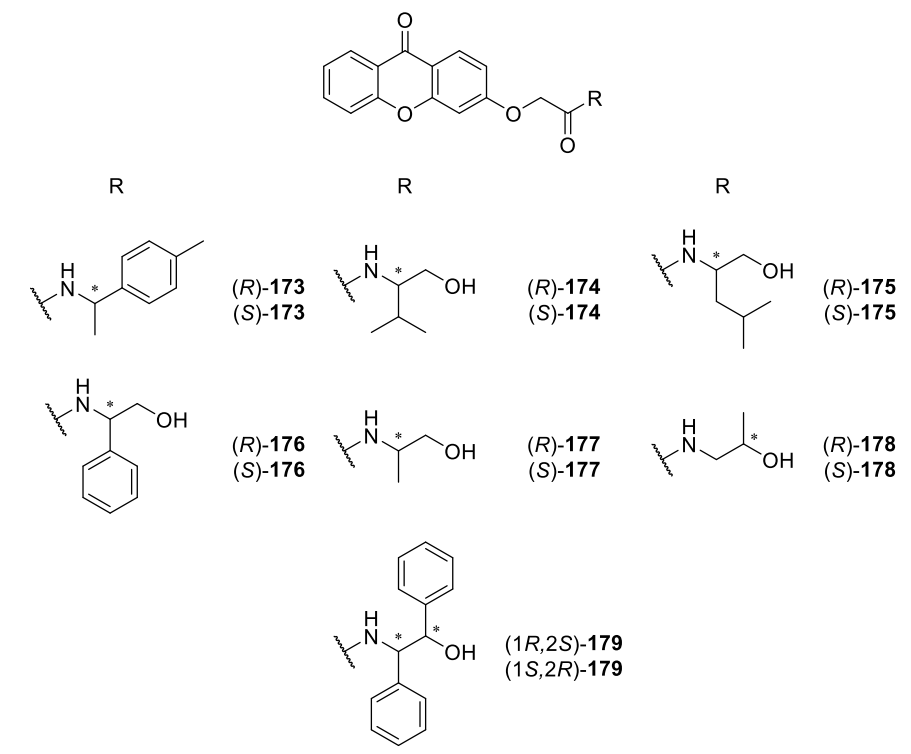

Figure 17. Structures of aminoalkanolic CDXs 174-179 and analogue 173.

Considering that carboxyxanthone derivatives are suitable molecular entities to perform molecular modifications to obtain new bioactive derivatives [34], the synthesis of all CDXs 165-179 were achieved by using two carboxyxanthone derivatives as substrates, namely 6-methoxy-9-oxo-9H-xanthene-2carboxylic acid and 2-((9-oxo-9H-xanthen-3-yl)oxy)acetic acid. The synthetic strategy used was the coupling of the carboxyxanthone derivatives with both enantiomers of eight commercially available chiral building blocks, using $O$-(benzotriazol-1-yl)- $N, N, N^{\prime}, N^{\prime}$-tetramethyluronium tetrafluoroborate (TBTU) as coupling reagent $[148,149]$. TBTU has been widely used as efficient reagent for the synthesis of diverse classes of compounds, including peptides [150], esters [151,152], phenylhydrazides [153], acid azides [154], among others. However, this was the first report of the use of TBTU to synthesize CDXs [149]. All used commercial chiral blocks included both enantiomers of enantiomerically pure 
building blocks with no tendency towards racemization or enantiomeric interconversion and having a primary amine as reactive group for amide formation. Amino alcohols, amines, and amino esters were selected. The coupling reactions were performed at room temperature, showing short reactions times and excellent yields (ranging from 94\% to 99\%) [148,149]. The synthetic methodology used to obtain the referred CDXs provided to be very efficient, broad-scope applicability, and operationally simplest. Moreover, it was found that the synthesis of the CDXs was easily scaled-up for both enantiomers in order to obtain available quantities for biological and pharmacological assays as well as other applications.

LC using different types of CSPs, namely polysaccharide-based [149], macrocyclic antibiotics [155,156], and Pirkle-type [157,158] was used for enantioresolution studies and determination of the enantiomeric purity of the synthesized CDXs. The enantioselective LC method using polysaccharide-based CSPs under multimodal elution conditions afforded very high resolutions with short chromatographic runs. The best performances were achieved on amylose tris-3,5dimethylphenylcarbamate stationary phase under polar organic elution conditions. The resolution achieved allowed the determination of the enantiomeric purity for all CDXs, affording values higher than $99 \%$ [149].

Considering the macrocyclic antibiotic-based CSPs, four commercially available columns were used, namely Chirobiotic $\mathrm{T}^{\mathrm{TM}}$, Chirobiotic $\mathrm{R}^{\mathrm{TM}}$, Chirobiotic $\mathrm{V}^{\mathrm{TM}}$ and Chirobiotic TAG ${ }^{\mathrm{TM}}$, under multimodal elution conditions. The optimized chiral LC conditions were successfully employed for the accurate determination of the enantiomeric purity, always higher than $99 \%$. The studies also explored the influence of different mobile phase compositions and $\mathrm{pH}$ on the chromatographic parameters as well as of the structural features of the CDXs on their chiral discrimination by the macrocyclic antibiotic-based CSPs $[155,156]$.

Regarding the Pirkle-type CSPs, the $(S, S)$-Whelk-O1 ${ }^{\circledR}$ CSP showed the best performance for the resolution of the CDXs evaluated, presenting very high enantioselectivity for CDXs with aromatic group linked to the chiral moiety. Polar organic elution mode presented the best chromatographic parameters allowing good resolutions and lower run time [157,158].

The overall results proved that, for the same enantiomeric pair of CDXs, the polysaccharide-based CSPs were the most efficient to separate the enantiomers of this group of compounds, since all the CDXs were enantioseparated with excellent enantioselectivity and resolution [159].

For each enantiomeric pair of the synthesized CDXs 165-179 the in vitro growth inhibitory activity in three human tumor cell lines, A375-C5 (melanoma), MCF-7 (breast adenocarcinoma), and NCI-H460 (non-small cell lung cancer), were evaluated [149]. The results obtained demonstrate that some CDXs exhibited interesting growth inhibitory effects on the tumor cell lines. The most active CDX in all human tumor cell lines was compound $(\mathbf{1} R, \mathbf{2 S}) \mathbf{- 1 7 9}$. Furthermore, it is important to highlight that the effects on the growth of the human tumor cell lines were attributed not only to the nature and positions of substituents on the xanthonic scaffold, but also, in some cases, were associated with the stereochemistry of the CDXs concerning enantioselectivity results. Interesting examples of enantioselectivity were observed between the enantiomeric pairs of CDXs 165, 167, and 171 [149].

Recently, other enantioselectivity studies associated with biological activity were conducted, specifically the in vitro and in silico inhibition of cyclooxygenases (COX-1 and COX-2) for the enantiomeric pairs of CDXs 166, 168 and 169 [160]. All CDXs exhibited COX-1 and COX-2 inhibition being, in general, the inhibitory effects similar for both COXs. The only exception was the enantiomeric pair of compound 166, being the $(R)-(+)$-enantiomer more active at inhibiting COX-2 than COX-1. Interestingly, all pairs demonstrated enantioselectivity for COX-1. Concerning COX-2, the \% of inhibition was also dependent of the stereochemistry being (S)-(-)-166 and (S)-(+)-169 more active [160].

Additionally, for the same enantiomeric pairs of CDXs 166, 168 and 169, human serum albumin (HSA) binding affinity was evaluated by spectrofluorimetry and in silico studies, by a docking approach [160]. All CDXs demonstrated to bind with high affinity to HSA and enantioselectivity was observed for compound 168. 
Taking into account that these CDXs have molecular moieties structurally very similar to local anaesthetics, the ability to block compound action potentials (CAP) at the isolated rat sciatic nerve was also investigated [161]. The CDXs (S)-165, (S)-166 and (S)-167 were chosen for biological evaluation and the results suggested that the nerve conduction blockade might result predominantly from an action on $\mathrm{Na}^{+}$ionic currents. It was also investigated if the CDXs could prevent hypotonic haemolysis on rat erythrocytes. However, data suggested that all tested CDXs caused no significant protection against hypotonic when applied in concentrations high enough to block the sciatic nerve conduction in the rat [161].

Besides the potential as new drugs, CDXs present structural features with interest as chiral selectors for LC [23]. In this context, some of these small molecules $((S)-\mathbf{1 6 7},(R)-\mathbf{1 6 8},(S)-\mathbf{1 6 8},(R)-\mathbf{1 7 6}$, $(1 R, 2 S)-179$ and $(1 S, 2 R)-179)$ were selected and bound to a chromatographic support for a new application as CSPs in LC [24]. The new xanthonic CSPs afforded promising enantioresolution results, high stability and reproducibility. Accordingly, CDXs have important applications in the field of Medicinal Chemistry, not only as candidates for potential new drugs but also as analytical tools for enantioseparation in LC [37].

Recently, our group also performed enantioselectivity studies with chiral thioxanthones, $S$-analogues of xanthones, as modulators of P-glycoprotein (P-gp) [162]. It was found that one of the enantiomers modulated P-gp expression differently from its pair.

Marona et col. [163-169] also described the synthesis and biological activity evaluation of a series of aminoalkanolic CDXs 180-205, 217-220, 238 (Figures 18-20). More recently, they synthesized the aminoalkanolic CDXs 206-243 (Figures 18-20), being tested for anticonvulsant, antimicrobial and cardiovascular activities [170-174]. CDXs 180-194, 198-202 were synthesized by condensation of an appropriate 2-bromomethylxanthone or 2-bromomethyl-7-chloroxanthone with the adequate aminoalkanol in toluene, in the presence of anhydrous potassium carbonate $[163,164,175]$. The exchange of secondary amino group of compound 189 for a tertiary amino group (compound 193) was generated by reductive $N$-methylation [163]. Compound 210, however, was synthesized through the chlorination of compound 186 with thionyl chloride in toluene [170].

Compounds 195-197, 221-223, 228-232 and 241-243 were synthesized by the aminolysis of 3- or 4-((oxiran-2-yl)methoxy)xanthone in n-propanol, or by the amination of 2-methyl-6-hydroxy-xanthone using propylene epichlorohydrin, in the presence of sodium hydroxide and water [167,172-174].

The synthesis of compounds 203-204, 206-209, 213-216, 224-227 and 240 involved a multi-step process. At first, a substituted benzoic acid reacted with 2- or 4-methylphenol in two steps involving an Ullmann condensation and electrophilic addition. The intermediate methyl derivatives of substituted xanthone were used in the reaction with $N$-bromosuccinimide giving appropriate bromide derivatives. The last step comprised an aminolysis by means of appropriate aminoalkanol carried out in toluene in the presence of anhydrous $\mathrm{K}_{2} \mathrm{CO}_{3}[171,176]$.

Most of the synthesized CDXs 180-209, 211-220, 224-227, 233-238, 240 were evaluated for anticonvulsant activity [163-167,169,171,175,177-179]. The studies involved three kind of tests: maximal electroshock-induced seizures (MES), subcutaneous pentetrazole seizure threshold (scMet), and neurological toxicity (TOX).

In one of the first MES assays in mice, 2-amino-1-propanol-, 1-amino-2-propanol and 1-amino-2-butanol derivatives of 6-methoxy- or 6-chloroxanthone were the most interesting compounds. In fact, the results indicated that compound $\mathbf{1 8 4}$ was the most active [163]. Further study compared the anticonvulsant activity of CDX 184 (racemate) with the single enantiomers $((R)-184,(S)-184)$. All the compounds showed excellent results, and no significant differences were observed in the anticonvulsant activity of the single enantiomers compared with the racemate [166].

Additionally, the enantiomeric purity of (R)-184 and (S)-184 was determined by a liquid chromatography-mass spectrometry method with an electrospray ionization interface (ESI-LC/MS). The separation of the two enantiomers $((R)-\mathbf{1 8 4}$ and $(S)-\mathbf{1 8 4})$ was carried out on the commercially 
available cellulose tris-(3,5-dimethylphenyl carbamate) CSP, Chiralcel ${ }^{\circledR}$ OD-RH, giving enantiomeric purity values higher than $99.9 \%$ [166].

Interesting anticonvulsant results were also observed with alkanolic chiral derivatives 189 and 193 of 7-chloroxanthone, which displayed anti-MES activity corresponding with that for phenytoin, carbamazepine and valproate [164]. Moreover, it is important to highlight that in this study some cases of enantioselectivity were observed. For example, although enantiomers $(R)-\mathbf{1 8 9}$ and $(S)-\mathbf{1 8 9}$ showed anticonvulsant activity, the $(S)$-enantiomer was more neurotoxic. Furthermore, considering the compound 193 (racemate), the $(R)$-enantiomer $((R)$-193) in comparison to $(S)$-enantiomer ((S)-193) showed higher anticonvulsant activity $[164,177]$. Recently, several aminoalkanolic chiral derivatives substituted in positions 2, 3, or 4 evaluated for their anticonvulsant activities with 2-xanthonoxy derivatives 206, 207 and 209, being the most active and exhibiting neurotoxicity after $30 \mathrm{~min}$ after administration at the dose of $100 \mathrm{mg} / \mathrm{kg}$ [171]. A further study including chiral aminoalkanol derivatives substituted in position 2 of the xanthonic scaffold (structures not shown) also emphasized the importance to examine biologically enantiomers other than racemates [178].

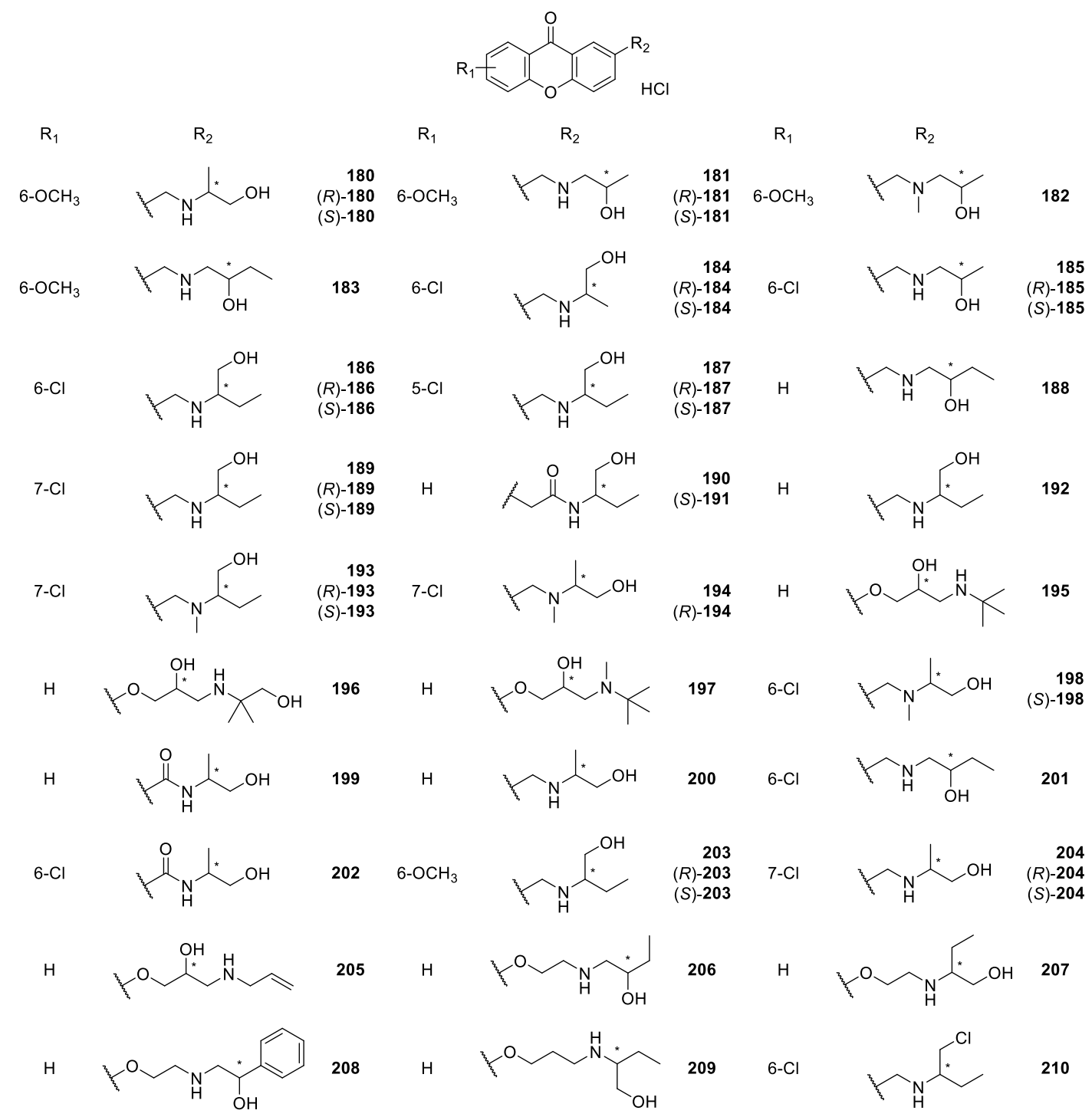

Figure 18. Structures of 2-aminoalkanolic CDXs 180-210. 


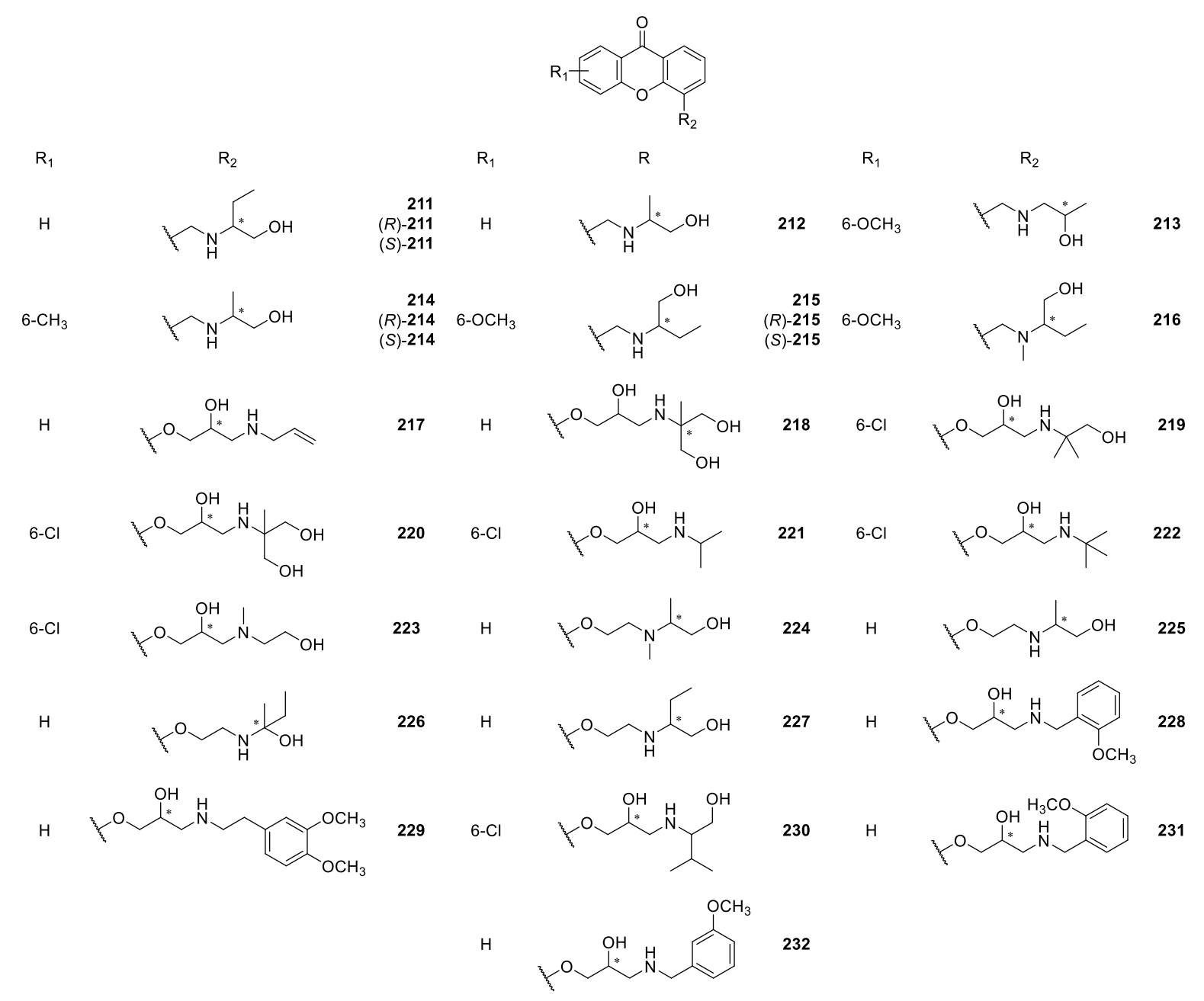

Figure 19. Structures of 4-aminoalkanolic CDXs 211-232.

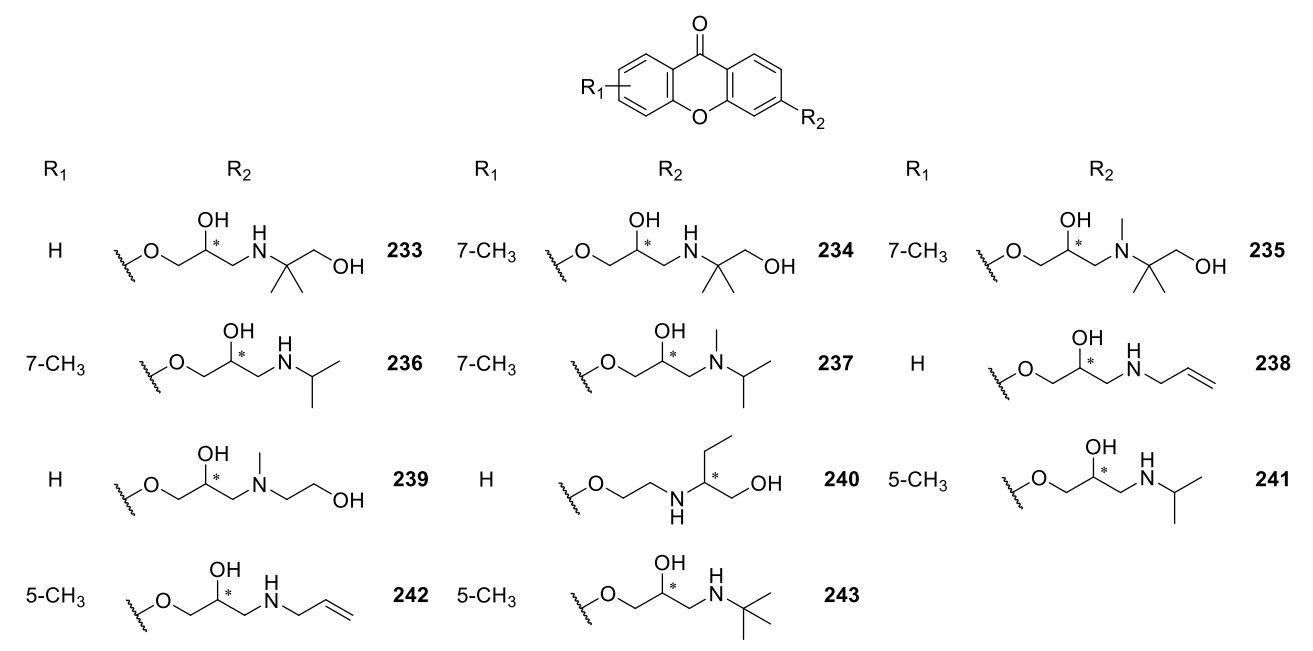

Figure 20. Structures of 3-aminoalkanolic CDXs 233-243.

Additionally, a structure-anticonvulsant activity relationship study was described including series of aminoalkanol derivatives 204, 213-216 of 6-methoxy- or 7-chloro-2-methylxanthone as well as 6-methoxy-4-methylxanthone [176]. All the compounds showed activity in the MES screening which is recognized as one of the two most widely used seizures models for early identification of candidates as anticonvulsants. The tested compounds were evaluated in the form of racemic 
mixture and some additionally in the form of single enantiomers to determine stereochemistry-activity relationship. In fact, as demonstrated before [176], stereochemistry is one of the factors that can potentially influenced anticonvulsant activity of the CDXs. However, considering anti-MES activity it was not possible to establish relationship between stereochemistry and anticonvulsant properties because all sets of compounds gave different results. Racemate and enantiomers showed either similar results or diverged in duration of activity or lower effective doses. However, the anticonvulsant activity was associated with both aminoalkanol type and respective configuration as well as the location of substitution in the xanthone scaffold [176]. The overall results from several studies of Marona et col. [163-167,171,175-179] are quite encouraging and suggested that in the group of xanthone derivatives new potential anticonvulsants might be found.

Some of alkanolic CDXs were also evaluated for cardiovascular activity $[167,173-175,179,180]$, including antiarrhythmic, hypotensive, $\alpha_{1}$ - and $\beta_{1}$-adrenergic blocking activities, effect on the normal electrocardiogram and influence on the central nervous system (CNS) [169]. Among the investigated compounds, some of them exhibited significant antiarrhythmic and/or hypotensive activity. For example, compounds 218 and 219 revealed the strongest anti-arrhythmic activity in the adrenaline-induced model of arrhythmia. Additionally, compound 219 was also the most potent concerning hypotensive activity [169]. Recently, compounds 231 and 232 were also evaluated for their cardiovascular activity, through both $\alpha_{1}$ - and $\beta_{1}$-adrenergic blocking. These compounds, classified as beta-blockers with vasodilating properties, exhibited also hypotensive vasorelaxant activities comparable to those of carvedilol [173].

The effects on platelet aggregation of racemic CDXs 180-182, 195 and 196, and the enantiomeric pure CDX $(R)-193$ were evaluated and showed motivating results. The most active and promising compound was $(R)-\mathbf{1 9 3}$ which nearly completely inhibited the thrombin aggregation concentration (TAC) [181]. The results indicated that the presence of the 2-N-methylamino-1-butanol at position 2 and the chloride atom at the 7-position of the xanthone scaffold promoted antiplatelets activity.

Alkanolic CDXs 180, 183, 184 and 194 were used to assess mutagenic and antimutagenic activities in assays using the Vibrio harveyi test [182]. According to the obtained results, the most beneficial mutagenic and antimutagenic profiles were observed for compound 194. This compound was shown to have strong antimutagenic activity towards the BB7 $V$. harveyi strain while failing to induce mutagenic responses in the tested strains. The modification of the chemical structure of compound 194 through chlorination of the hydroxyl group, improved considerably the antimutagenic activity maintaining the inability to induce mutagenic responses in the strains. Thus, antimutagenic potency reached a maximum with the presence of tertiary amine and one chloride atom in the side chain. Minimal activity was showed to compound $\mathbf{1 8 4}$ and no antimutagenic activity was observed for compound 180 [182].

In recent years, several aminoalkanolic CDXs 210, 228-230, 241-242 have been evaluated for their antibacterial and antifungal activities [170,172]. Compound 210 was evaluated against several dermatophytes, moulds and yeasts, exhibiting good activity results against ten strains of the Aspergillus fumigatus, niger and flavus moulds, being among the tested compounds the most active [170]. This CDX also exhibited moderate to good activity against some strains of the Trichophyton mentagrophytes and rubum dermatophytes, while being inactive against the Candida albicans yeast [170].

The antimicrobial activity of CDXs 228-230, 241-242 against 12 strains of the bacteria Helicobacter pylori was evaluated through the Kirby-Bauer method, by measuring the diameters of inhibition zones, showing that compounds 228, 230, 241-242 exhibited strong activity against the strains ATCC 43504, 700684 and 43504. Actually, those CDXs were considered the best of the tested compounds, while compound 229, demonstrated weak antibacterial activity [172].

In a recent study on the influence of reactive oxygen species (ROS) in the anticancer activity of aminoalkanolic derivatives, it was reported that in the case of CDXs 219 and 223, ROS were of great importance to their proapoptotic activity [183]. These encouraging results suggested that aminoalkanolic CDXs might be interesting structures for potential use in anticancer therapy [183]. 


\subsubsection{CDXs Conjuged with Amines, Amino Esters and Amino Acids}

Inspired by natural xanthones properties, Rakesh et al. [184] synthesize xanthone derivatives with conjugated L-amino acids (244-263, Figure 21), to determine the corresponding antimicrobial and anti-inflammatory activities. The same research group recently reported the evaluation of in vitro anticancer activity of those compounds, against three different cancer cell lines, MCF-7, MDA-MB-435 and A549, validated by DNA binding and molecular docking approaches [185].

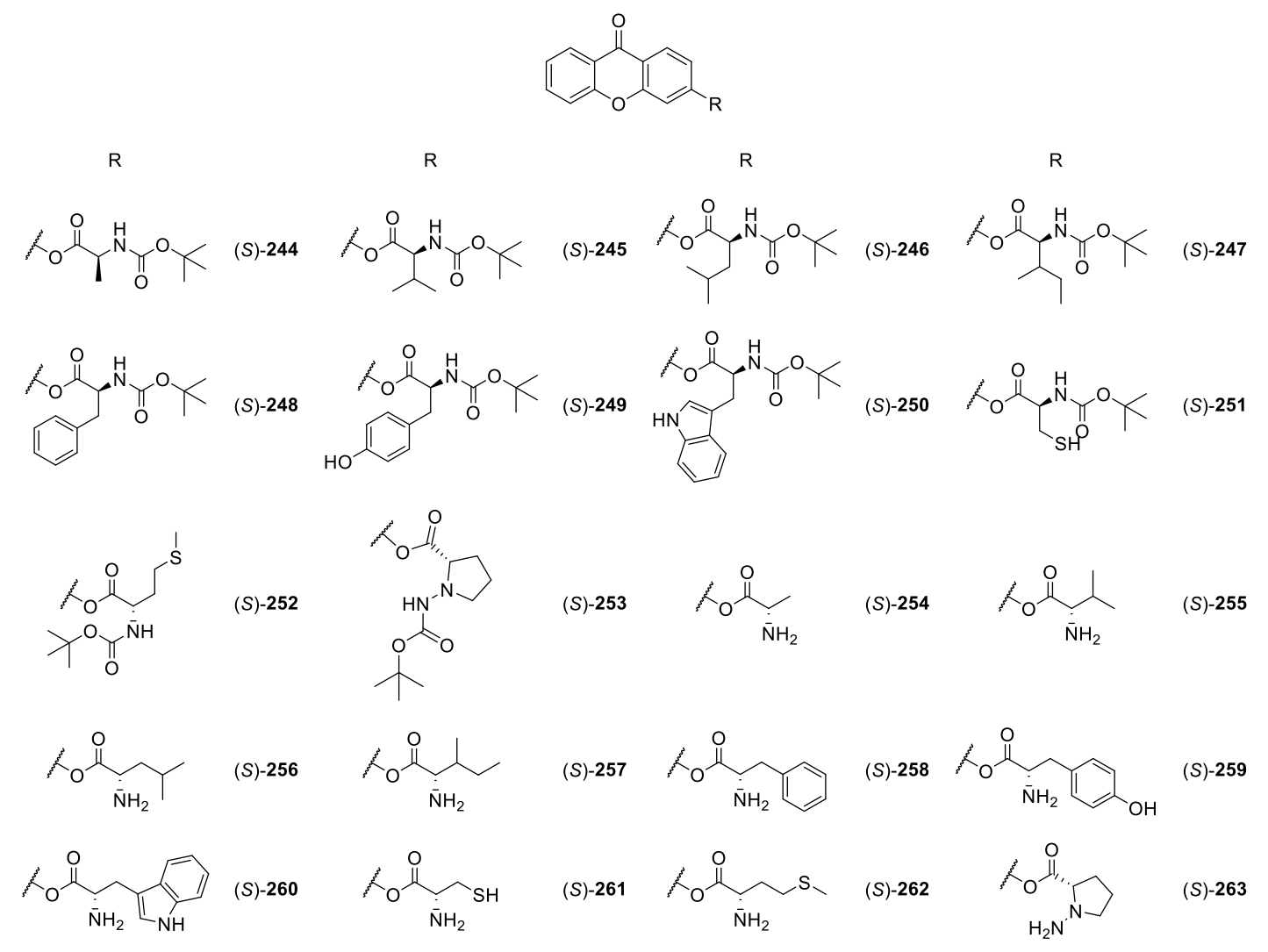

Figure 21. Structures of CDXs 244-263, with antimicrobial and anti-inflammatory activities.

The synthetic strategy used to obtain the compounds was accomplished using 2-chlorobenzoic acid and resorcinol in anhydrous zinc chloride to give 2-chlorophenyl-(2,4-dihydroxyphenyl) methanone and cyclized with DMSO and $\mathrm{NaOH}$ to give 3-hydroxyxanthone. This chemical substrate was, afterwards, conjugated with different protected amino acids [184,185].

The compounds with the best antimicrobial and anti-inflammatory activities were those conjugated with L-phenylalanine, L-tyrosine and L-tryptophan, followed by compounds conjugated with L-cysteine, L-methionine and L-proline [184]. Additionally, the compounds with amino acids with high aromaticity and hydrophobicity, presented more stable amphiphilic structures.

The antimicrobial effect comes from the penetration of the amino acid hydrophobic chains in the bacterial membranes where the cationic moiety of the amino acids interacts with the membrane phospholipids disturbing bacterial membrane. This strategy proved to be effective to develop new antimicrobial agents [184], as the microorganism die without developing mutations or resulting in loss of recognition by the antibiotics [96]. Other studies accomplished the same conclusions [168,172,186]. Regarding the antitumor activity, the compounds (S)-248, (S)-249 and (S)-250 exhibited potent inhibition against the tested tumor cell lines as well as DNA binding. The SAR studies showed that the aromatic and hydrophobic amino acids, such as phenylalanine, tyrosine, and tryptophan, favored the DNA binding studies and antitumor activities; whereas, aliphatic amino acids showed 
lower activity. The derivatives with glycine, alanine, valine, leucine, and isoleucine showed less or moderate anticancer properties [185].

\subsubsection{CDXs Containing Piperazine Moieties and Analogues}

Several CDXs containing piperazine moieties (267-270, 272-294) and analogues $(\mathbf{2 6 4}, \mathbf{2 6 5}, \mathbf{2 7 1})$ were synthesized (Figures 22-24) and their biological activity evaluated by Marona's group [165,167, $168,172,173,181,187-192]$.

2-Hydroxyxanthone was the building block used to synthesize compounds $267-273$ and 277 using epichorhydrin in the presence of pyridine [165]. Compounds 274-276, 278, 280-282 were synthesized by amination of 2-(2-bromoethoxy)-9H-xanthen-9-one and derivatives in $n$-propanol or toluene in the presence of $\mathrm{K}_{2} \mathrm{CO}_{3}$ [187]. The compounds 283-284, 292-293 were obtained by aminolysis of 4-[(2,3-epoxy)propoxy]xanthone with appropriate 1-piperazine derivatives in $n$-propanol, while $\mathbf{2 7 9}$ was synthesized using the same methodology through the aminolysis of 3-[(2,3-epoxy)propoxy]xanthone [172,173,188].

Chiral compounds 287-291 were obtained by amination of respective parent compounds [189] with appropriate amines in $n$-propanol. In addition, compound 287 was obtained from compound 286 by acetylation. In order to optimize synthetic methodologies, CDX 286 was obtained using an alternative method including $(R, S)$-4-(3-chloro-2-hydroxypropoxy)-9H-xanthen-9-one as intermediate [189].

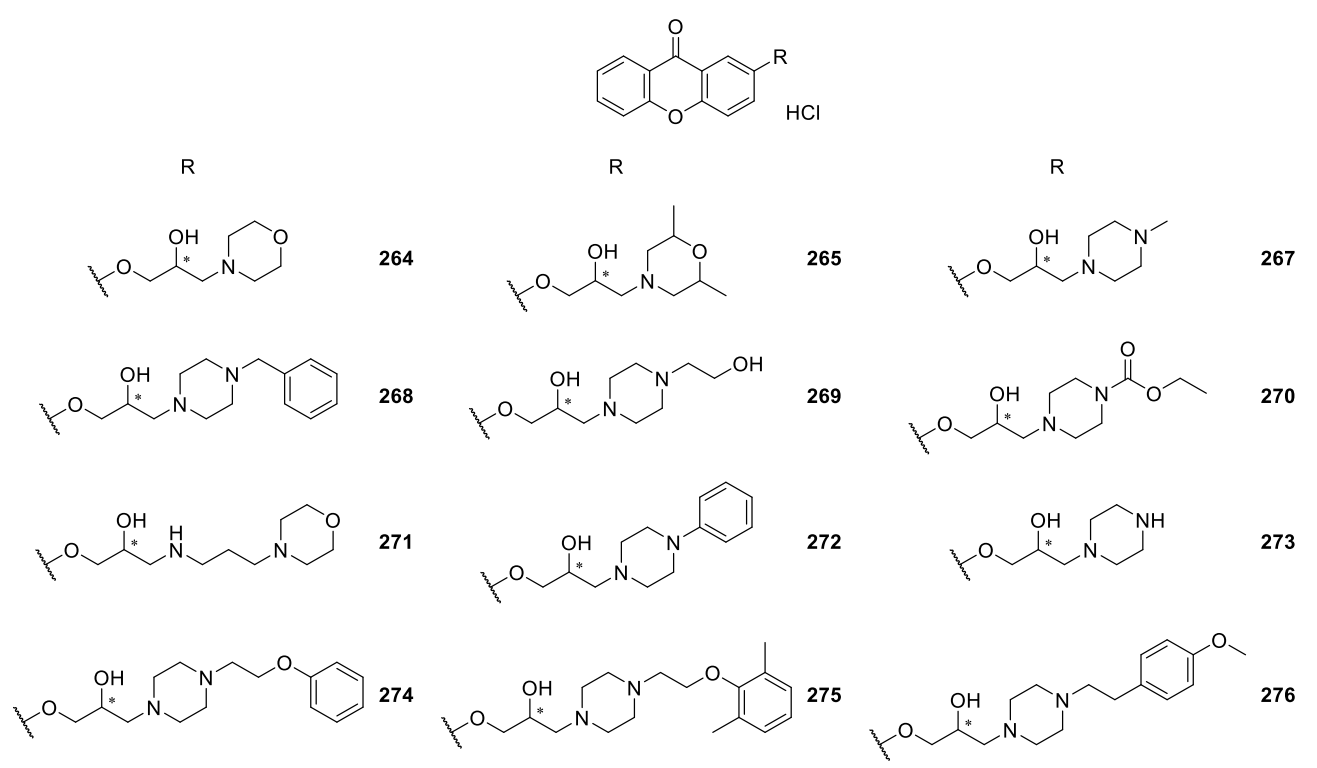

Figure 22. Structures of 2-piperazine derivatives 264-276.

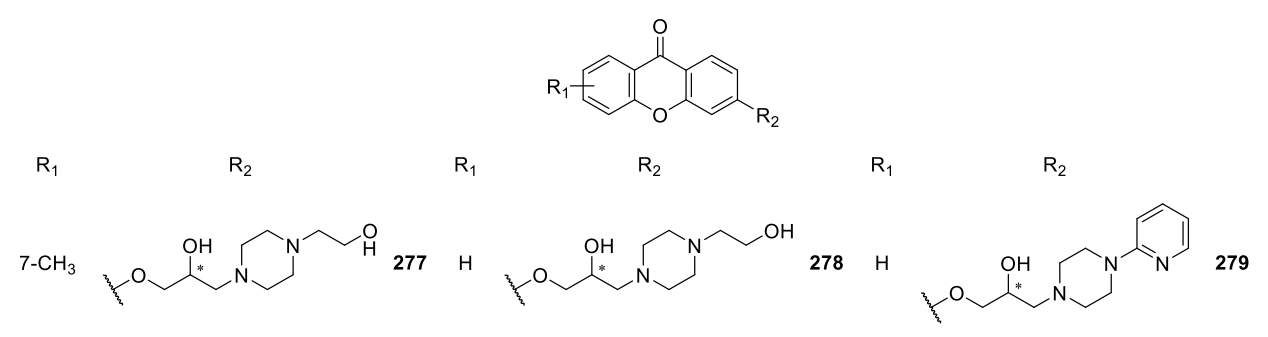

Figure 23. Structures of 3-piperazine derivatives 277-279. 


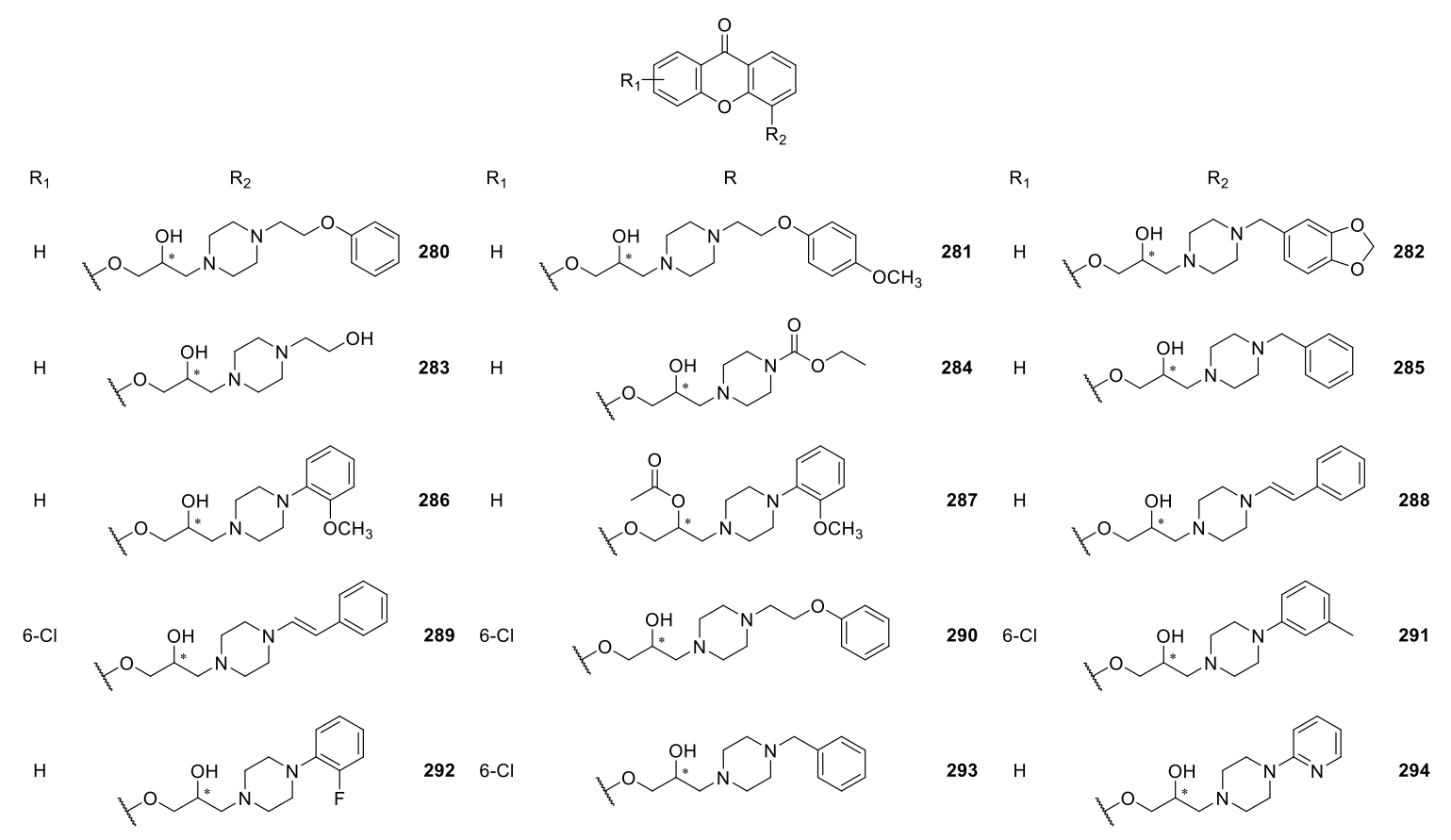

Figure 24. Structures of 4-piperazine derivatives 280-294.

CDXs 267-273 and 277 were evaluated for anticonvulsant activity in the MES- and subcutaneous pentylenetrazole-induzed seizures in mice and rats [165]. Among them, the most promising compound was CDX 268 which was active in both the anticonvulsant tests.

Moreover, the influence on the platelet aggregation of CDXs 264, 265, 269 and 271 was evaluated by using adenosine-5'-diphosphate (ADP), sodium arachidonate (AA) or thrombin as the aggregating agents [181]. CDXs 265 and 271 were active, inducing 80-90\% inhibition of thrombin-stimulated platelet aggregation.

Considering that the xanthone itself proved to possess vasorelaxing properties in thoracic aorta isolated from rats [193] and the strongest hypotensive effects were observed for compounds containing piperazine moiety [189], several compounds that combine the xanthone nucleus and piperazine rings (274-276, 278-291) were evaluated for anti-arrhythmic and/or antihypertensive activities. It is important to emphasize that CDXs 274 and 280 demonstrated to possess significant anti-arrhythmic activity in the adrenaline-induced model of arrhythmia [187]. The strongest hypotensive activity which persisted for $60 \mathrm{~min}$ was also associated to compound $\mathbf{8 9}$.

Additionally, in another study related to the same biological activities, compound $\mathbf{9 6}$ was the most promising considering its effect on circulatory system. Moreover, this CDX diminished arterial blood pressure by about $40 \%$ during one hour [188].

A recent cardiovascular activity study of several CDXs 286-291 was described, including the following pharmacological experiments: the binding affinity for adrenoceptors, the influence on the normal electrocardiogram, the effect on the arterial blood pressure and prophylactic antiarrhythmic activity in adrenaline induced model of arrhythmia (rats, iv) [189]. The CDXs 286 and 287 revealed to act as potential antiarrhythmics in adrenaline induced model of arrhythmia in rats after intravenous injection. In another study, CDX 279 was reported as a promising hypotensive with its activity attributed to the blockage of $\alpha 1$-adrenoreceptors [173]. The results obtained were quite encouraging and suggested that in the group of xanthone derivatives new potential antiarrhythmics and hypotensives might be found. 
Table 2. Summary of the biological activities of synthetic CDXs obtained by binding/coupling chiral moieties to the xanthone scaffold.

\begin{tabular}{ccc}
\hline CDXs & Biological Activities & Ref. \\
\hline & Antitumor, & {$[122-133,136]$} \\
XAA, DMXAA and analogues 156-164 & antiviral, & {$[134]$} \\
& antiplatelet, antithrombotic, & {$[135]$} \\
& anti-inflammatory & {$[137]$} \\
& and analgesic & {$[140]$} \\
\hline & Cyclooxygenases inhibition, & {$[160]$} \\
Aminoalkanolic CDXs 165-243 & antitumor, & {$[148]$} \\
& anticonvulsant, & {$[139-163,167,171,175-179]$} \\
& antiplatelet aggregation, & {$[167,169,173-175,179,180]$} \\
ansters and amino acids 244-263 & antimutagenic, & {$[181]$} \\
& antifungal, & {$[182]$} \\
\hline & antibacterial and & {$[170]$} \\
CDXs containing piperazine moieties & anticancer & {$[172]$} \\
and analogues 264-294 & Anti-inflammatory & {$[183]$} \\
\hline CDXs containing other moieties & antiplatelet aggregation, & {$[168,172,186]$} \\
295-310 & cardiovascular, & {$[165]$} \\
\hline & antifungal and & {$[181]$} \\
\hline
\end{tabular}

A series of some chiral derivatives of 2-xanthones $267-273,277$ with a piperazine moiety was evaluated for their activity against $M$. tuberculosis. The highest level of activity against $M$. tuberculosis was observed for compound $\mathbf{2 7 0}$, which exhibited $94 \%$ growth inhibition. This compound was also examined for its anti-M. avium activity as well as cytotoxicity, showing insignificant anti M. avium activity and cytotoxic effects [188].

Recently, CDXs 284-285, 290, 292, 293 were evaluated for their antibacterial activity against 12 strains of the bacteria Helicobacter pylori [172]. CDX 285 showed strong activity against H. pylori strain ATCC 43504 and 700684, being the only compound to show higher activity against clarithromycin-resistant $H$. Pylori strains, than to the one resistant to metronidazole [172].

\subsubsection{CDXs Containing Other Moieties}

Recently, Cherkadu et al. [194] reported the synthesis of some CDXs 295-310 (Figure 25) containing moieties other than piperazine and aminoalcohols [194]. The synthesis of these CDXs, a series of 2-(aminobenzothiazol)methylxanthones, was performed through the reaction of 3-hydroxy-xanthone, aromatic aldehydes and 2-aminobenzothiazoles in $\mathrm{DMF}$ at $120^{\circ} \mathrm{C}$ with $\mathrm{FeCl}_{3}$ as catalyst [194]. To the best of our knowledge, no biological activities were reported for those CDXs.

A summary of the synthetic CDXs obtained by binding/coupling chiral moieties to the xanthone scaffold, their biological activities as well as the associated references are presented in Table 2. 
<smiles>[R]C(Nc1nc2c(C)cccc2s1)c1c(O)ccc2c(=O)c3ccccc3oc12</smiles><smiles>[R]C(Nc1nc2c(Cl)cccc2s1)c1c(O)ccc2c(=O)c3ccccc3oc12</smiles><smiles>[R]C(Nc1nc2cccc(Cl)c2s1)c1c(O)ccc2c(=O)c3ccccc3oc12</smiles><smiles>[R]c1c(O)ccc2c(=O)c3ccccc3oc12</smiles>

R<smiles>CCC(C)c1ccc(OC)cc1</smiles>
295<smiles></smiles>
298

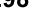

$\mathrm{R}$<smiles>CC(C)c1ccccc1</smiles>
296<smiles>COc1ccc(C(C)C)cc1</smiles>
297<smiles>CC(C)(C)c1ccccc1</smiles>
299<smiles>Cc1ccc(C(C)C)cc1</smiles>
300 302<smiles>CC(C)c1cccc(Oc2ccccc2)c1</smiles>
303 305<smiles>CC(C)c1ccc(C#N)cc1</smiles>
306 308<smiles>CC(C)c1ccc([N+](=O)[O-])cc1</smiles>
309

Figure 25. Structures of CDXs 295-310.

\section{Conclusions}

The synthetic CDXs, inspired in natural sources, and obtained by coupling chiral moieties to the xanthone scaffold, demonstrated potential to perform a large variety of biological activities, including antitumor, antimicrobial, anticonvulsant, antimalarial, anti-inflammatory, antiplatelet, anti- thrombotic, antipyretic, analgesic, antioxidant, antidiabetic, anticoagulant, among others. Nevertheless, for this family of compounds the main biological activities reported were antitumor and antimicrobial.

The more studied chiral moieties were amines, amino alcohols and amino acids. The cationic moieties of the amino acids have been indicated as a good approach to develop new antimicrobial agents both for CDXs inspired in natural xanthones and obtained by coupling chiral moieties to the xanthone scaffold. Regarding enantioselectivity, some studies reported the importance in SAR studies, but the majority neglected the influence of stereochemistry in the biological activity.

Author Contributions: C.F, M.L.C, J.R. and J.A collected the primary data and contributed in writing of the manuscript. M.E.T., C.F. and M.M.M.P. supervised the development of the manuscript, and assisted in data interpretation, manuscript evaluation, and editing.

Funding: This work was supported by the Strategic Funding UID/Multi/04423/2013 through national funds provided by FCT - Foundation for Science and Technology and European Regional Development Fund (ERDF), in the framework of the programme PT2020, the project PTDC/MAR-BIO/4694/2014 (reference POCI-01-0145-FEDER-016790; Project 3599 - Promover a Produção Científica e Desenvolvimento Tecnológico e a Constituição de Redes Temáticas (3599-PPCDT)) as well as by Project No. POCI-01-0145-FEDER-028736, co-financed by COMPETE 2020, under the PORTUGAL 2020 Partnership Agreement, through the European Regional Development Fund (ERDF), and CHIRALXANT-CESPU-2018. 
Conflicts of Interest: The authors declare no conflict of interest.

\section{References}

1. Tiritan, M.E.; Ribeiro, A.R.; Fernandes, C.; Pinto, M. Chiral pharmaceuticals. In Kirk-Othmer Encyclopedia of Chemicl Technology; John Wiley \& Sons, Inc.: Hoboken, NJ, USA, 2016.

2. Calcaterra, A.; D'Acquarica, I. The market of chiral drugs: Chiral switches versus de novo enantiomerically pure compounds. J. Pharm. Biomed. Anal. 2018, 147, 323-340. [CrossRef] [PubMed]

3. Caner, H.; Groner, E.; Levy, L.; Agranat, I. Trends in the development of chiral drugs. Drug Discov. Today 2004, 9, 105-110. [CrossRef]

4. Blaser, H.U. Chirality and its implications for the pharmaceutical industry. Rend. Lincei. 2013, 24, $213-216$. [CrossRef]

5. Mannschreck, A.; Kiesswetter, R.; von Angerer, E. Unequal activities of enantiomers via biological receptors: Examples of chiral drug, pesticide, and fragrance molecules. J. Chem. Ed. 2007, 84, 2012-2017. [CrossRef]

6. Triggle, D.J. Stereoselectivity of drug action. Drug Discov. Today 1997, 2, 138-147. [CrossRef]

7. Cordato, D.J.; Mather, L.E.; Herkes, G.K. Stereochemistry in clinical medicine: A neurological perspective. J. Clin. Neurosci. 2003, 10, 649-654. [CrossRef]

8. Smith, S.W. Chiral toxicology: It's the same thing only different. Toxicol. Sci. 2009, 110, 4-30. [CrossRef] [PubMed]

9. Silva, B.; Fernandes, C.; Tiritan, M.E.; Pinto, M.M.M.; Valente, M.J.; Carvalho, M.; de Pinho, P.G.; Remião, F. Chiral enantioresolution of cathinone derivatives present in "legal highs", and enantioselectivity evaluation on cytotoxicity of 3,4-methylenedioxypyrovalerone (mdpv). Forensic. Toxicol. 2016, 34, 372-385. [CrossRef] [PubMed]

10. Silva, B.; Fernandes, C.; de Pinho, P.G.; Remião, F. Chiral resolution and enantioselectivity of synthetic cathinones: A brief review. J. Anal. Toxicol. 2018, 42, 17-24. [CrossRef] [PubMed]

11. Caldwell, J. Importance of stereospecific bioanalytical monitoring in drug development. J. Chromatogr. A 1996, 719, 3-13. [CrossRef]

12. Andrushko, V.; Andrushko, N. Stereoselective Synthesis of Drugs and Natural Products; Jonh Wiley \& Sons: Hoboken, NJ, USA, 2013; Volume 2, p. 1836.

13. Bhadra, S.; Yamamoto, H. Substrate directed asymmetric reactions. Chem. Rev. 2018, 118, 3391-3446. [CrossRef] [PubMed]

14. Karimi, B.; Tavakolian, M.; Akbari, M.; Mansouri, F. Ionic liquids in asymmetric synthesis: An overall view from reaction media to supported ionic liquid catalysis. ChemCatChem 2018, 10, 3173-3205. [CrossRef]

15. Xue, Y.P.; Cao, C.H.; Zheng, Y.G. Enzymatic asymmetric synthesis of chiral amino acids. Chem. Soc. Rev. 2018, 47, 1516-1561. [CrossRef] [PubMed]

16. Fernandes, C.; Tiritan, M.E.; Pinto, M.M.M. Chiral separation in preparative scale: A brief overview of membranes as tools for enantiomeric separation. Symmetry 2017, 9, 206. [CrossRef]

17. Ward, T.J.; Ward, K.D. Chiral separations: A review of current topics and trends. Anal. Chem. 2012, 84, 626-635. [CrossRef] [PubMed]

18. Francotte, E.R. Enantioselective chromatography as a powerful alternative for the preparation of drug enantiomers. J. Chromatogr. A 2001, 906, 379-397. [CrossRef]

19. Haginaka, J. Pharmaceutical and biomedical applications of enantioseparations using liquid chromatographic techniques. J. Pharm. Biomed. Anal. 2002, 27, 357-372. [CrossRef]

20. Council of the European Communities. Investigation of Chiral Active Substances. Directive 75/318/EEC; Council of the European Communities: Brussels, Belgium, 1993.

21. FDA. Fda's policy statement for the development of new stereoisomeric drugs. Fed. Reg. 1992, 57, 249.

22. Shimazawa, R.; Nagai, N.; Toyoshima, S.; Okuda, H. Present state of new chiral drug development and review in Japan. J. Health Sci. 2008, 54, 23-29. [CrossRef]

23. Fernandes, C.; Phyo, Y.Z.; Silva, A.S.; Tiritan, M.E.; Kijjoa, A.; Pinto, M.M.M. Chiral stationary phases based on small molecules: An update of the last 17 years. Sep. Purif. Rev. 2018, 47, 89-123. [CrossRef]

24. Fernandes, C.; Tiritan, M.E.; Cravo, S.; Phyo, Y.Z.; Kijjoa, A.; Silva, A.M.S.; Cass, Q.B.; Pinto, M.M.M. New chiral stationary phases based on xanthone derivatives for liquid chromatography. Chirality 2017, 29, 430-442. [CrossRef] [PubMed] 
25. Ribeiro, J.; Tiritan, M.E.; Pinto, M.M.M.; Fernandes, C. Chiral stationary phases for liquid chromatography based on chitin- and chitosan-derived marine polysaccharides. Symmetry 2017, 9, 190. [CrossRef]

26. Lämmerhofer, M. Chiral recognition by enantioselective liquid chromatography: Mechanisms and modern chiral stationary phases. J. Chromatogr. A 2010, 1217, 814-856. [CrossRef] [PubMed]

27. Gales, L.; Damas, A.M. Xanthones-a structural perspective. Curr. Med. Chem. 2005, 12, 2499-2515. [CrossRef] [PubMed]

28. Muthukrishnan, M.; Basavanag, U.M.V.; Puranik, V.G. The first ionic liquid-promoted kabbe condensation reaction for an expeditious synthesis of privileged bis-spirochromanone scaffolds. Tetrahedron. Lett. 2009, 50, 2643-2648. [CrossRef]

29. Horton, D.A.; Bourne, G.T.; Smythe, M.L. The combinatorial synthesis of bicyclic privileged structures or privileged substructures. Chem. Rev. 2003, 103, 893-930. [CrossRef] [PubMed]

30. Waseem, S.; Ahmad, I. Recent insight into the biological activities of synthetic xanthone derivatives. Eur. J. Med. Chem. 2016, 116, 267-280.

31. Pinto, M.; Sousa, M.; Nascimento, M. Xanthone derivatives: New insights in biological activities. Curr. Med. Chem. 2005, 12, 2517-2538. [CrossRef]

32. Wezeman, T.; Brase, S.; Masters, K.S. Xanthone dimers: A compound family which is both common and privileged. Nat. Prod. Rep. 2015, 32, 6-28. [CrossRef] [PubMed]

33. Na, Y. Recent cancer drug development with xanthone structures. J. Pharm. Pharmacol. 2009, 61, 707-712. [CrossRef] [PubMed]

34. Ribeiro, J.; Veloso, C.; Fernandes, C.; Tiritan, M.E.; Pinto, M.M.M. Carboxyxanthones: Bioactive agents and molecular scaffold for synthesis of analogues and derivatives. Molecules 2019, 24, 180. [CrossRef] [PubMed]

35. Sathyadevi, P.; Chen, Y.J.; Wu, S.C.; Chen, Y.H.; Wang, Y.M. Reaction-based epoxide fluorescent probe for in vivo visualization of hydrogen sulfide. Biosens. Bioelectron. 2015, 68, 681-687. [CrossRef] [PubMed]

36. Takashima, I.; Kawagoe, R.; Hamachi, I.; Ojida, A. Development of an and logic-gate-type fluorescent probe for ratiometric imaging of autolysosome in cell autophagy. Chem. Eur. J. 2015, 21, 2038-2044. [CrossRef] [PubMed]

37. Fernandes, C.; Tiritan, M.E.; Pinto, M.M.M. Chiral derivatives of xanthones: Applications in medicinal chemistry and a new approach in liquid chromatography. Sci. Chromatogr. 2015, 7, 1-14.

38. Masters, K.S.; Brase, S. Xanthones from fungi, lichens, and bacteria: The natural products and their synthesis. Chem. Rev. 2012, 112, 3717-3776. [CrossRef] [PubMed]

39. Vieira, L.M.; Kijjoa, A. Naturally-occurring xanthones: Recent developments. Curr. Med. Chem. 2005, 12, 2413-2446. [CrossRef] [PubMed]

40. Pinto, M.M.M.; Castanheiro, R.A.P.; Kijjoa, A. Xanthones from marine-derived microorganisms: Isolation, structure elucidation, and biological activities. In Encyclopedia of Analytical Chemistry, 1st ed.; John Wiley \& Sons: Hoboken, NJ, USA, 2014; Volume 27, pp. 1-21.

41. Sousa, M.; Pinto, M. Synthesis of xanthones: An overview. Curr. Med. Chem. 2005, 12, 2447-2479. [CrossRef] [PubMed]

42. Azevedo, C.; Afonso, C.; Pinto, M. Routes to xanthones: An update on the synthetic approaches. Curr. Org. Chem. 2012, 16, 2818-2867. [CrossRef]

43. Lanzotti, V. Drugs based on natural compounds: Recent achievements and future perspectives. Phytochem. Rev. 2014, 13, 725-726. [CrossRef]

44. Michael, A. On the action of aromatic oxy-acids on phenols. Am. Chem. J. 1883, 5, 81-97.

45. V Kostanecki, S. Über das gentisin. Monatsh. Chem. 1891, 12, 205-210. [CrossRef]

46. Goldberg, I. Ueber Phenylirungen bei Gegenwart von Kupfer als Katalysator. Chem. Ber. 1906, 39, $1691-1692$. [CrossRef]

47. Chen, M.T.; Kuoh, Y.P.; Wang, C.H.; Chen, C.M.; Kuoh, C.S. Additional constituents of hypericum subalatum. J. Chin. Chem. Soc. 1988, 36, 165-168. [CrossRef]

48. Wu, Q.-L.; Wang, S.-P.; Du, L.-J.; Yang, J.-S.; Xiao, P.-G. Xanthones from hypericum japonicum and h. Henryi. Phytochemistry 1998, 49, 1395-1402. [CrossRef]

49. Pinto, M.; Sousa, E. Natural and synthetic xanthonolignoids: Chemistry and biological activities. Curr. Med. Chem. 2003, 10, 1-12. [CrossRef] [PubMed]

50. Gottlieb, O.R.; Mesquita, A.A.L.; Silva, E.M.; Melo, T. Xanthones of kielmeyera ferruginea. Phytochemistry 1969, 8, 665-666. [CrossRef] 
51. Pinto, M.M.D.M.; Mesquita, A.A.L.; Gottlieb, O.R. Xanthonolignoids from kielmeyera coriacea. Phytochemistry 1987, 26, 2045-2048. [CrossRef]

52. Tanaka, H.; Ishihara, M.; Ichino, K.; Ohiwa, N.; Ito, K. Total synthesis of a xanthonolignoid, kielcorin. Chem. Pharm. Bull. 1989, 37, 1916-1918. [CrossRef]

53. Vishwakarma, R.; Kapil, R.S.; Popli, S.P. Total synthesis of Keilcorin. Indian J. Chem. Sect. B 1986, $25,1021$.

54. Fernandes, E.G.R.; Pinto, M.M.M.; Silva, A.M.S.; Cavaleiro, J.A.S.; Gottlieb, O.R. Synthesis and structural elucidation of xanthonolignoids: Trans- $( \pm)$ - kielcorin $b$ and trans- $( \pm)$-isokielcorin $b$. Heterocycles 1999, 51 , 821-828.

55. Saraiva, L.; Fresco, P.; Pinto, E.; Sousa, E.; Pinto, M.; Gonçalves, J. Synthesis and in vivo modulatory activity of protein kinase $\mathrm{c}$ of xanthone derivatives. Bioorg. Med. Chem. 2002, 10, 3219-3227. [CrossRef]

56. Sousa, E.P.; Silva, A.; Pinto, M.M.; Pedro, M.M.; Cerqueira, F.A.; Nascimento, M.S. Isomeric kielcorins and dihydroxyxanthones: Synthesis, structure elucidation, and inhibitory activities of growth of human cancer cell lines and on the proliferation of human lymphocytes in vitro. Helv. Chim. Acta 2002, 85, 2862-2876. [CrossRef]

57. Saraiva, L.; Fresco, P.; Pinto, E.; Sousa, E.; Pinto, M.; Gonçalves, J. Inhibition of $\alpha, \beta i, \delta, \eta$ and $\zeta$ protein kinase c isoforms by xanthonolignoids. J. Enzyme. Inhib. Med. Chem. 2003, 18, 357-370. [CrossRef] [PubMed]

58. Fernandas, E.R.; Carvalho, F.D.; Remião, F.G.; Bastos, M.L.; Pinto, M.M.; Gottlieb, O.R. Hepatoprotective activity of xanthones and xanthonolignoids against tert-butylhydroperoxide-induced toxicity in isolated rat hepatocytes-comparison with silybin. Pharm. Res. 1995, 12, 1756-1760. [CrossRef]

59. Sousa, E.P.; Tiritan, M.; Oliveira, R.V.; Afonso, C.; Cass, Q.; Pinto, M.M. Enantiomeric resolution of kielcorin derivatives by hplc on polysaccharide stationary phases using multimodal elution. Chirality 2004, 16, 279-285. [CrossRef]

60. Sousa, M.E.; Tiritan, M.E.; Belaz, K.R.A.; Pedro, M.; Nascimento, M.S.J.; Cass, Q.B.; Pinto, M.M.M. Multimilligram enantioresolution of low-solubility xanthonolignoids on polysaccharide chiral stationary phases using a solid-phase injection system. J. Chromatogr. A 2006, 1120, 75-81. [CrossRef]

61. Kupchan, S.M.; Streelman, D.R.; Sneden, A.T. Psorospermin, a new antileukemic xanthone from psorospermum febrifugum. J. Nat. Prod. 1980, 43, 296-301. [CrossRef]

62. Schwaebe, M.K.; Moran, T.J.; Whitten, J.P. Total synthesis of psorospermin. Tetrahedron. Lett. 2005, 46, 827-829. [CrossRef]

63. Heald, R.A.; Dexheimer, T.S.; Vankayalapati, H.; Siddiqui-Jain, A.; Szabo, L.Z.; Gleason-Guzman, M.C.; Hurley, L.H. Conformationally restricted analogues of psorospermin: Design, synthesis, and bioactivity of natural-product-related bisfuranoxanthones. J. Med. Chem. 2005, 48, 2993-3004. [CrossRef] [PubMed]

64. Fellows, I.M.; Schwaebe, M.; Dexheimer, T.S.; Vankayalapati, H.; Gleason-Guzman, M.; Whitten, J.P.; Hurley, L.H. Determination of the importance of the stereochemistry of psorospermin in topoisomerase ii-induced alkylation of DNA and in vitro and in vivo biological activity. Mol. Cancer Ther. 2005, 4, 1729-1739. [CrossRef] [PubMed]

65. Ayensu, E.S. Medicinal Plants of West Africa; Reference Publications Inc.: Algonac, MI, USA, 1978.

66. Kodama, T.; Ito, T.; Dibwe, D.F.; Woo, S.Y.; Morita, H. Syntheses of benzophenone-xanthone hybrid polyketides and their antibacterial activities. Bioorg. Med. Chem. Lett. 2017, 27, 2397-2400. [CrossRef]

67. Dibwe, D.; Awale, S.; Kadota, S.; Tezuka, Y. Muchimangins a-d: Novel diphenylmethyl-substituted xanthones from securidaca longepedunculata. Tetrahedron. Lett. 2012, 53, 6186-6190. [CrossRef]

68. Gold-Smith, F.; Fernandez, A.; Bishop, K. Mangiferin and cancer: Mechanisms of action. Nutrients 2016, 8, 396. [CrossRef] [PubMed]

69. Zheng, M.; Lu, Z. Antiviral effect of mangiferin and isomangiferin on herpes simplex virus. Chin. Med. J. 1990, 103, 160-165. [PubMed]

70. Zhu, X.; Song, J.; Huang, Z.; Wu, Y.; Yu, M. Antiviral activity of mangiferin against herpes simplex virus type 2 in vitro. Acta Pol. Pharm. Sinica. 1993, 14, 452-454.

71. Yoosook, C.; Bunyapraphatsara, N.; Boonyakiat, Y.; Kantasuk, C. Anti-herpes simplex virus activities of crude water extracts of thai medicinal plants. Phytomedicine 2000, 6, 411-419. [CrossRef]

72. Benard, O.; Chi, Y. Medicinal properties of mangiferin, structural features, derivative synthesis, pharmacokinetics and biological activities. Mini-Rev. Med. Chem. 2015, 15, 582-594. [CrossRef]

73. Imran, M.; Arshad, M.S.; Butt, M.S.; Kwon, J.H.; Arshad, M.U.; Sultan, M.T. Mangiferin: A natural miracle bioactive compound against lifestyle related disorders. Lip. Health Dis. 2017, 16, 84. [CrossRef] 
74. Araújo, J.; Fernandes, C.; Pinto, M.; Tiritan, M. Chiral derivatives of xanthones with antimicrobial activity. Molecules 2019, 24, 314. [CrossRef]

75. Singh, S.; Tiwari, R.; Sinha, S.; Danta, C.; Prasad, S. Antimicrobial evaluation of mangiferin and its synthesized analogues. Asian Pac. J. Trop. Biomed. 2012, 2, S884-S887. [CrossRef]

76. Singh, S.; Sinha, S.; Prasad, S.; Kumar, R.; Bithu, B.; Kumar, S.; Singh, P. Synthesis and evaluation of novel analogues of mangiferin as potent antipyretic. Asian Pac. J. Trop. Biomed. 2011, 4, 866-869. [CrossRef]

77. Dar, A.; Faizi, S.; Naqvi, S.; Roome, T.; Zikr-ur-Rehman, S.; Ali, M.; Firdous, S.; Moin, S. Analgesic and antioxidant activity of mangiferin and its derivatives: The structure activity relationship. Biol. Pharm. Bull. 2005, 28, 596-600. [CrossRef] [PubMed]

78. Mahendran, S.; Badami, S.; Ravi, S.; Thippeswamy, B.; Veerapur, V. Synthesis and evaluation of analgesic and anti-inflammatory activities of most active free radical scavenging derivatives of mangiferin. Bri. J. Appl. Sci. Technol. 2014, 4, 4959-4973. [CrossRef]

79. Miura, T.; Ichiki, H.; Iwamoto, N.; Kato, M.; Kubo, M.; Sasaki, H.; Okada, M.; Ishida, T.; Seino, Y.; Tanigawa, K. Antidiabetic activity of the rhizoma of anemarrhena asphodeloides and active components, mangiferin and its glucoside. Biol. Pharm. Bull. 2001, 24, 1009-1011. [CrossRef] [PubMed]

80. Miura, T.; Ichiki, H.; Hashimoto, I.; Iwamoto, N.; Kao, M.; Kubo, M.; Ishihara, E.; Komatsu, Y.; Okada, M.; Ishida, T.; et al. Antidiabetic activity of a xanthone compound, mangiferin. Phytomedicine 2001, 8, 85-87. [CrossRef] [PubMed]

81. Hu, H.G.; Wang, M.J.; Zhao, Q.J.; Yu, S.C.; Liu, C.M.; Wu, Q.Y. Synthesis of mangiferin derivates and study their potent ptp1b inhibitory activity. Chin. Chem. Lett. 2007, 18, 1323-1326. [CrossRef]

82. Hu, H.; Wang, M.; Zhao, Q.; Liao, H.; Cai, L.; Song, Y.; Zhang, J.; Yu, S.; Chen, W.; Liu, C.; et al. Synthesis of mangiferin derivatives as protein tyrosine phosphatase $1 \mathrm{~b}$ inhibitors. Chem. Nat. Compd. 2007, 43. [CrossRef]

83. Li, X.; Du, Z.; Huang, Y.; Liu, B.; Hu, W.; Lu, W.; Deng, J. Synthesis and hypoglycemic activity of esterified-derivatives of mangiferin. Chin. J. Nat. Med. 2013, 11, 296-301. [CrossRef]

84. Klaman, L.; Boss, O.; Peroni, O.; Kim, J.; Martino, J.; Zabolotny, J.; Moghal, N.; Lubkin, M.; Kim, Y.; Sharpe, A.; et al. Increased energy expenditure, decreased adiposity, and tissue-specific insulin sensitivity in protein-tyrosine phosphatase 1b-deficient mice. Mol. Cell. Biol. 2000, 20, 5479-5489. [CrossRef]

85. Elchebly, M.; Payette, P.; Michaliszyn, E.; Cromlish, W.; Collins, S.; Loy, A.; Normandin, D.; Cheng, A.; Himms-Hagen, J.; Chan, C.; et al. Increased insulin sensitivity and obesity resistance in mice lacking the protein tyrosine phosphatase-1b gene. Science 1999, 283, 1544-1548. [CrossRef]

86. Correia-da-Silva, M.; Sousa, E.; Duarte, B.; Marques, F.; Carvalho, F.; Cunha-Ribeiro, L.; Pinto, M. Polysulfated xanthones: Multipathway development of a new generation of dual anticoagulant/antiplatelet agents. J. Med. Chem. 2011, 54, 5373-5384. [CrossRef] [PubMed]

87. Kaomongkolgit, R.; Jamdez, K.; Chaisomboon, N. Antifungal activity of alpha-mangostin against candida albicans. J. Oral. Sci. 2009, 51, 401-406. [CrossRef] [PubMed]

88. Jung, H.; Su, B.; Keller, W.; Mehta, R.; Kinghorn, A. Antioxidant xanthones from the pericarp of garcinia mangostana (mangosteen). J. Agric. Food. Chem. 2006, 54. [CrossRef] [PubMed]

89. Guzman-Beltran, S.; Rubio-Badillo, M.A.; Juarez, E.; Hernandez-Sanchez, F.; Torres, M. Nordihydroguaiaretic acid (ndga) and alpha-mangostin inhibit the growth of mycobacterium tuberculosis by inducing autophagy. Int. Immunopharmacol. 2016, 31, 149-157. [CrossRef] [PubMed]

90. Xu, Z.; Huang, L.; Chen, X.H.; Zhu, X.F.; Qian, X.J.; Feng, G.K.; Lan, W.J.; Li, H.J. Cytotoxic prenylated xanthones from the pericarps of garcinia mangostana. Molecules 2014, 19, 1820-1827. [CrossRef]

91. Sudta, P.; Jiarawapi, P.; Suksamrarn, A.; Hongmanee, P.; Suksamrarn, S. Potent activity against multidrug-resistant mycobacterium tuberculosis of $\alpha$-mangostin analogs. Chem. Pharm. Bull. 2013, 61, 194-203. [CrossRef] [PubMed]

92. Chen, L.; Yang, L.; Wang, C. Anti-inflammatory activity of mangostins from garcinia mangostana. Food Chem. Toxicol. 2008, 46, 688-693. [CrossRef] [PubMed]

93. Iikubo, K.; Ishikawa, Y.; Ando, N.; Umezawab, K.; Nishiyama, S. The first direct synthesis of alfa-mangostin, a potent inhibitor of the acidic sphingomyelinase. Tetrahedron. Lett. 2002, 43. [CrossRef]

94. Suksamrarn, S.; Suwannapoch, N.; Phakhodee, W.; Thanuhiranlert, J.; Ratananukul, P.; Chimnoi, N.; Suksamrarn, A. Antimycobacterial activity of prenylated xanthones from the fruits of garcinia mangostana. Chem. Pharm. Bull. 2003, 51, 857-859. [CrossRef] [PubMed] 
95. Koh, J.J.; Zou, H.; Mukherjee, D.; Lin, S.; Lim, F.; Tan, J.K.; Tan, D.; Stocker, B.L.; Timmer, M.; Corkran, H.M.; et al. Amphiphilic xanthones as a potent chemical entity of anti-mycobacterial agents with membrane-targeting properties. Eur. J. Med. Chem. 2016, 123, 684-703. [CrossRef] [PubMed]

96. Li, J.; Liu, S.; Koh, J.J.; Zou, H.; Lakshminarayanan, R.; Bai, Y.; Pervushin, K.; Zhou, L.; Verma, C.; Beuerman, R.W. A novel fragment based strategy for membrane active antimicrobials against mrsa. BBA-Biomembranes 2015, 1848, 1023-1031. [CrossRef] [PubMed]

97. Lin, S.; Koh, J.J.; Aung, T.T.; Lim, F.; Li, J.; Zou, H.; Wang, L.; Lakshminarayanan, R.; Verma, C.; Wang, Y.; et al. Symmetrically substituted xanthone amphiphiles combat gram-positive bacterial resistance with enhanced membrane selectivity. J. Med. Chem. 2017, 60, 1362-1378. [CrossRef] [PubMed]

98. Zou, H.; Koh, J.J.; Li, J.; Qiu, S.; Aung, T.T.; Lin, H.; Lakshminarayanan, R.; Dai, X.; Tang, C.; Lim, F.H.; et al. Design and synthesis of amphiphilic xanthone-based, membrane-targeting antimicrobials with improved membrane selectivity. J. Med. Chem. 2013, 56, 2359-2373. [CrossRef] [PubMed]

99. Koh, J.J.; Lin, S.; Aung, T.T.; Lim, F.; Zou, H.; Bai, Y.; Li, J.; Lin, H.; Pang, L.M.; Koh, W.L.; et al. Amino acid modified xanthone derivatives: Novel, highly promising membrane-active antimicrobials for multidrug-resistant gram-positive bacterial infections. J. Med. Chem. 2015, 58, 739-752. [CrossRef] [PubMed]

100. Ren, Y.; Lantvit, D.D.; Carcache de Blanco, E.J.; Kardono, L.B.; Riswan, S.; Chai, H.; Cottrell, C.E.; Farnsworth, N.R.; Swanson, S.M.; Ding, Y.; et al. Proteasome-inhibitory and cytotoxic constituents of garcinia lateriflora: Absolute configuration of caged xanthones. Tetrahedron 2010, 66, 5311-5320. [CrossRef] [PubMed]

101. Ren, Y.; Yuan, C.; Chai, H.B.; Ding, Y.; Li, X.C.; Ferreira, D.; Kinghorn, A.D. Absolute configuration of (-)-gambogic acid, an antitumor agent. J. Nat. Prod. 2011, 74, 460-463. [CrossRef] [PubMed]

102. Rukachaisirikul, V.; Kaewnok, W.; Koysomboon, S.; Phongpaichit, S.; Taylor, W.C. Caged-tetraprenylated xanthones from garcinia scortechinii. Tetrahedron 2000, 56, 8539-8543. [CrossRef]

103. Sukpondma, Y.; Rukachaisirikul, V.; Phongpaichit, S. Antibacterial caged-tetraprenylated xanthones from the fruits of garcinia hanburyi. Chem. Pharm. Bull. 2005, 53, 850-852. [CrossRef] [PubMed]

104. Banik, K.; Harsha, C.; Bordoloi, D.; Lalduhsaki Sailo, B.; Sethi, G.; Leong, H.C.; Arfuso, F.; Mishra, S.; Wang, L.; Kumar, A.P.; et al. Therapeutic potential of gambogic acid, a caged xanthone, to target cancer. Cancer Lett. 2018, 416, 75-86. [CrossRef] [PubMed]

105. Chaiyakunvat, P.; Anantachoke, N.; Reutrakul, V.; Jiarpinitnun, C. Caged xanthones: Potent inhibitors of global predominant mrsa usa300. Bioorg. Med. Chem. Lett. 2016, 26, 2980-2983. [CrossRef]

106. Ke, H.; Morrisey, J.M.; Qu, S.; Chantarasriwong, O.; Mather, M.W.; Theodorakis, E.A.; Vaidya, A.B. Caged garcinia xanthones, a novel chemical scaffold with potent antimalarial activity. Antimicrob. Agents Chemother. 2017, 61. [CrossRef] [PubMed]

107. Reutrakul, V.; Anantachoke, N.; Pohmakotr, M.; Jaipetch, T.; Sophasan, S.; Yoosook, C.; Kasisit, J.; Napaswat, C.; Santisuk, T.; Tuchinda, P. Cytotoxic and anti-hiv-1 caged xanthones from the resin and fruits of garcinia hanburyi. Planta Med. 2007, 73, 33-40. [CrossRef] [PubMed]

108. Alam, S.; Khan, F. Virtual screening, docking, admet and system pharmacology studies on garcinia caged xanthone derivatives for anticancer activity. Sci. Rep. 2018, 8, 5524. [CrossRef] [PubMed]

109. Batova, A.; Altomare, D.; Chantarasriwong, O.; Ohlsen, K.L.; Creek, K.E.; Lin, Y.C.; Messersmith, A.; Yu, A.L.; $\mathrm{Yu}, \mathrm{J}$.; Theodorakis, E.A. The synthetic caged garcinia xanthone cluvenone induces cell stress and apoptosis and has immune modulatory activity. Mol. Cancer Ther. 2010, 9, 2869-2878. [CrossRef] [PubMed]

110. Chantarasriwong, O.; Cho, W.C.; Batova, A.; Chavasiri, W.; Moore, C.; Rheingold, A.L.; Theodorakis, E.A. Evaluation of the pharmacophoric motif of the caged garcinia xanthones. Org. Biomol. Chem. 2009, 7, 4886-4894. [CrossRef]

111. Batova, A.; Lam, T.; Wascholowski, V.; Yu, A.L.; Giannis, A.; Theodorakis, E.A. Synthesis and evaluation of caged garcinia xanthones. Org. Biomol. Chem. 2007, 5, 494-500. [CrossRef] [PubMed]

112. Elbel, K.M.; Guizzunti, G.; Theodoraki, M.A.; Xu, J.; Batova, A.; Dakanali, M.; Theodorakis, E.A. A-ring oxygenation modulates the chemistry and bioactivity of caged garcinia xanthones. Org. Biomol. Chem. 2013, 11, 3341-3348. [CrossRef]

113. Li, X.; Wu, Y.; Wang, Y.; You, Q.; Zhang, X. 'Click chemistry' synthesis of novel natural product-like caged xanthones bearing a 1,2,3-triazole moiety with improved druglike properties as orally active antitumor agents. Molecules 2017, 22, 1834. [CrossRef] 
114. Li, X.; Zhang, X.; Wang, X.; Li, N.; Lin, C.; Gao, Y.; Yu, Z.; Guo, Q.; You, Q. Synthesis and anti-tumor evaluation of b-ring modified caged xanthone analogues of gambogic acid. Chin. J. Chem. 2012, 30, 35-42. [CrossRef]

115. Wu, Y.; Hu, M.; Yang, L.; Li, X.; Bian, J.; Jiang, F.; Sun, H.; You, Q.; Zhang, X. Novel natural-product-like caged xanthones with improved druglike properties and in vivo antitumor potency. Bioorg. Med. Chem. Lett. 2015, 25, 2584-2588. [CrossRef]

116. Xu, X.; Wu, Y.; Hu, M.; Li, X.; Bao, Q.; Bian, J.; You, Q.; Zhang, X. Novel natural product-like caged xanthones bearing a carbamate moiety exhibit antitumor potency and anti-angiogenesis activity in vivo. Sci. Rep. 2016, 6, 35771. [CrossRef] [PubMed]

117. Miao, G.; Ma, J.; Yang, K.; Huang, Z.; Gu, Q.; Wang, Y.; Guo, Q.; You, Q.; Wang, J. Synthesis and bioevaluation of novel oxa-caged garcinia xanthones as anti-tumour agents. Aust. J. Chem. 2015, 68, 872. [CrossRef]

118. Koh, J.J.; Lin, S.; Bai, Y.; Sin, W.; Aung, T.T.; Li, J.; Chandra, V.; Pervushin, K.; Beuerman, R.; Liu, S. Antimicrobial activity profiles of amphiphilic xanthone derivatives are a function of their molecular oligomerization. BBA-Biomembranes 2018, 860, 2281-2298. [CrossRef] [PubMed]

119. Cho, W.C. Synthesis of Caged Garcinia Xanthone Analogues; University of California: San Diego, CA, USA, 2009.

120. Zhang, X.; Li, X.; Sun, H.; Jiang, Z.; Tao, L.; Gao, Y.; Guo, Q.; You, Q. Synthesis and evaluation of novel aza-caged garcinia xanthones. Org. Biomol. Chem. 2012, 10, 3288-3299. [CrossRef] [PubMed]

121. Rewcastle, G.W.; Atwell, G.J.; Zhuang, L.; Baguley, B.C.; Denny, W.A. Potential antitumor agents. 61. Structure-activity relationships for in vivo colon 38 activity among disubstituted 9-oxo-9h-xanthene-4-acetic acids. J. Med. Chem. 1991, 34, 217-222. [CrossRef] [PubMed]

122. Baguley, B.C.; McKeage, M.J. Asa404: A tumor vascular-disrupting agent with broad potential for cancer therapy. Future Oncol. 2010, 6, 1537-1543. [CrossRef] [PubMed]

123. Head, M.; Jameson, M.B. The development of the tumor vascular-disrupting agent asa404 (vadimezan, dmxaa): Current status and future opportunities. Expert Opin. Investig. Drugs 2010, 19, 295-304. [CrossRef]

124. Rehman, F.; Rustin, G. Asa404: Update on drug development. Expert Opin. Investig. Drugs 2008, 17, 1547-1551. [CrossRef]

125. Ching, L.M. Asa404. Vascular-disrupting agent, oncolytic. Drugs Future 2008, 33, 561-569. [CrossRef]

126. McKeage, M.J.; Kelland, L.R. 5,6-dimethylxanthenone-4-acetic acid (dmxaa): Clinical potential in combination with taxane-based chemotherapy. Am. J. Cancer 2006, 5, 155-162. [CrossRef]

127. Baguley, B.C.; Wilson, W.R. Potential of dmxaa combination therapy for solid tumors. Expert Rev. Anticanc. 2002, 2, 593-603. [CrossRef] [PubMed]

128. Baguley, B.C. Antivascular therapy of cancer: Dmxaa. Lancet. Oncol. 2003, 4, 141-148. [CrossRef]

129. McKeage, M. Clinical trials of vascular disrupting agents in advanced non-small-cell lung cancer. Clin. Lung Cancer 2011, 12, 143-147. [CrossRef] [PubMed]

130. Zhou, S.; Kestell, P.; Baguley, B.C.; Paxton, J.W. 5,6-dimethylxanthenone-4-acetic acid (dmxaa): A new biological response modifier for cancer therapy. Invest. New Drugs 2002, 20, 281-295. [CrossRef] [PubMed]

131. Daei Farshchi Adli, A.; Jahanban-Esfahlan, R.; Seidi, K.; Samandari-Rad, S.; Zarghami, N. An overview on vadimezan (dmxaa): The vascular disrupting agent. Chem. Biol. Drug. Des. 2018, 91, 996-1006. [CrossRef] [PubMed]

132. Gomes, A.S.; Brandao, P.; Fernandes, C.S.G.; da Silva, M.; de Sousa, M.; Pinto, M.M.M. Drug-like properties and adme of xanthone derivatives: The antechamber of clinical trials. Curr. Med. Chem. 2016, 23, 3654-3686. [CrossRef] [PubMed]

133. Jameson, M.B.; Head, M. Pharmacokinetic evaluation of vadimezan (asa404, 5,6-dimethylxanthenone-4acetic acid, dmxaa). Expert Opin. Drug Metab. Toxicol. 2011, 7, 1315-1326. [CrossRef] [PubMed]

134. Shirey, K.A.; Nhu, Q.M.; Yim, K.C.; Roberts, Z.J.; Teijaro, J.R.; Farber, D.L.; Blanco, J.C.; Vogel, S.N. The anti-tumor agent, 5,6-dimethylxanthenone-4-acetic acid (dmxaa), induces ifn- $\beta$-mediated antiviral activity in vitro and in vivo. J. Leukoc. Biol. 2011, 89, 351-357. [CrossRef] [PubMed]

135. Zhang, S.H.; Zhang, Y.; Shen, J.; Zhang, S.; Chen, L.; Gu, J.; Mruk, J.S.; Cheng, G.; Zhu, L.; Kunapuli, S.P.; et al. Tumor vascular disrupting agent 5,6-dimethylxanthenone-4-acetic acid inhibits platelet activation and thrombosis via inhibition of thromboxane a2 signaling and phosphodiesterase. J. Thromb. Haemo. 2013, 11, 1855-1866. 
136. Rewcastle, G.W.; Atwell, G.J.; Baguley, B.C.; Boyd, M.; Thomsen, L.L.; Zhuang, L.; Denny, W.A. Potential antitumor agents. 63. Structure-activity relationships for side-chain analogs of the colon 38 active agent 9-oxo-9h-xanthene-4-acetic acid. J. Med. Chem. 1991, 34, 2864-2870. [CrossRef]

137. Nakanishi, M.; Oe, T.; Tsuruda, M.; Matsuo, H.; Sakuragi, S. Studies on anti inflammatory agents. Xxxi. Studies on the synthesis and anti inflammatory activity of xanthenyl and benzo pyranopyridinylacetic acid derivatives (japanese). yakugaku zasshi 1976, 96, 99-109. [CrossRef] [PubMed]

138. Marona, H. [synthesis of some 2-xanthonylmethylthioalkanoic acids.]. Acta Pol. Pharm. 1988, 45, 13-34.

139. Marona, H.; Pȩkala, E.; Gunia, A.; Czuba, Z.; Szneler, E.; Sadowski, T.; Król, W. The influence of some xanthone derivatives on the activity of j-774a.1 cells. Sci. Pharm. 2009, 77, 743-754. [CrossRef]

140. Żelaszczyk, D.; Lipkowska, A.; Szkaradek, N.; Słoczyńska, K.; Gunia-Krzyżak, A.; Librowski, T.; Marona, H. Synthesis and preliminary anti-inflammatory evaluation of xanthone derivatives. Heterocycl. Commun. 2018, 24, 231-236. [CrossRef]

141. Sousa, E.; Paiva, A.; Nazareth, N.; Gales, L.; Damas, A.M.; Nascimento, M.S.; Pinto, M. Bromoalkoxyxanthones as promising antitumor agents: Synthesis, crystal structure and effect on human tumor cell lines. Eur. J. Med. Chem. 2009, 44, 3830-3835. [CrossRef] [PubMed]

142. Sousa, E.; Palmeira, A.; Cordeiro, A.S.; Sarmento, B.; Ferreira, D.; Lima, R.T.; Vasconcelos, M.H.; Pinto, M. Bioactive xanthones with effect on p-glycoprotein and prediction of intestinal absorption. Med. Chem. Res. 2013, 22, 2115-2123. [CrossRef]

143. Cruz, I.; Puthongking, P.; Cravo, S.; Palmeira, A.; Cidade, H.; Pinto, M.; Sousa, E. Xanthone and flavone derivatives as dual agents with acetylcholinesterase inhibition and antioxidant activity as potential anti-alzheimer agents. J. Chem-Ny 2017, 2017. [CrossRef]

144. Neves, M.P.; Cidade, H.; Pinto, M.; Silva, A.M.; Gales, L.; Damas, A.M.; Lima, R.T.; Vasconcelos, M.H.; de Sao Jose Nascimento, M. Prenylated derivatives of baicalein and 3,7-dihydroxyflavone: Synthesis and study of their effects on tumor cell lines growth, cell cycle and apoptosis. Eur. J. Med. Chem. 2011, 46, 2562-2574. [CrossRef]

145. Paiva, A.M.; Sousa, M.E.; Camoes, A.; Nascimento, M.S.J.; Pinto, M.M.M. Prenylated xanthones: Antiproliferative effects and enhancement of the growth inhibitory action of 4-hydroxytamoxifen in estrogen receptor-positive breast cancer cell line. Med. Chem. Res. 2012, 21, 552-558. [CrossRef]

146. Azevedo, C.M.; Afonso, C.M.; Soares, J.X.; Reis, S.; Sousa, D.; Lima, R.T.; Vasconcelos, M.H.; Pedro, M.; Barbosa, J.; Gales, L.; et al. Pyranoxanthones: Synthesis, growth inhibitory activity on human tumor cell lines and determination of their lipophilicity in two membrane models. Eur. J. Med. Chem. 2013, 69, 798-816. [CrossRef]

147. Urbatzka, R.; Freitas, S.; Palmeira, A.; Almeida, T.; Moreira, J.; Azevedo, C.; Afonso, C.; Correia-da-Silva, M.; Sousa, E.; Pinto, M.; et al. Lipid reducing activity and toxicity profiles of a library of polyphenol derivatives. Eur. J. Med. Chem. 2018, 151, 272-284. [CrossRef] [PubMed]

148. Fernandes, C.; Masawang, K.; Tiritan, M.E.; Sousa, E.; De Lima, V.; Afonso, C.; Bousbaa, H.; Sudprasert, W.; Pedro, M.; Pinto, M.M. New chiral derivatives of xanthones: Synthesis and investigation of enantioselectivity as inhibitors of growth of human tumor cell lines. Bioorg. Med. Chem. 2014, 22, 1049-1062. [CrossRef] [PubMed]

149. Fernandes, C.; Brandão, P.; Santos, A.; Tiritan, M.E.; Afonso, C.; Cass, Q.B.; Pinto, M.M. Resolution and determination of enantiomeric purity of new chiral derivatives of xanthones using polysaccharide-based stationary phases. J. Chromatogr. A 2012, 1269, 143-153. [CrossRef] [PubMed]

150. Arabanian, A.; Mohammadnejad, M.; Balalaie, S. A novel and efficient approach for the amidation of c-terminal peptides. J. Iran Chem. Soc. 2010, 7, 840-845. [CrossRef]

151. Twibanire, J.D.K.; Grindley, T.B. Efficient and controllably selective preparation of esters using uronium-based coupling agents. Org. Lett. 2011, 13, 2988-2991. [CrossRef] [PubMed]

152. Balalaie, S.; Mahdidoust, M.; Eshaghi-Najafabadi, R. 2-(1h-benzotriazole-1-yl)-1,1,3,3-tetramethyluronium tetrafluoro borate (tbtu) as an efficient coupling reagent for the esterification of carboxylic acids with alcohols and phenols at room temperature. Chin. J. Chem. 2008, 26, 1141-1144. [CrossRef]

153. Balalaie, S.; Mahdidoust, M.; Eshaghi-Najafabadi, R. 2-(1h-benzotriazole-1-yl)-1, 1, 3, 3-tetramethyluronium tetrafluoroborate as an efficient coupling reagent for the amidation and phenylhydrazation of carboxylic acids at room temperature. J. Iran Chem. Soc. 2007, 4, 364-369. [CrossRef] 
154. Naik, S.A.; Lalithamba, H.S.; Sureshbabu, V.V. Application of 2-(1h-benzotriazol-1-yl)-1,1,3,3-tetramethyl uronium tetrafluoroborate (tbtu) for the synthesis of acid azides. Indian J. Chem. Sect. 2011, 50, 103-109. [CrossRef]

155. Fernandes, C.; Tiritan, M.E.; Cass, Q.; Kairys, V.; Fernandes, M.X.; Pinto, M. Enantioseparation and chiral recognition mechanism of new chiral derivatives of xanthones on macrocyclic antibiotic stationary phases. J. Chromatogr. A 2012, 1241, 60-68. [CrossRef]

156. Phyo, Y.Z.; Cravo, S.; Palmeira, A.; Tiritan, M.E.; Kijjoa, A.; Pinto, M.M.M.; Fernandes, C. Enantiomeric resolution and docking studies of chiral xanthonic derivatives on chirobiotic columns. Molecules 2018, 23, 142. [CrossRef]

157. Fernandes, C.; Palmeira, A.; Santos, A.; Tiritan, M.E.; Afonso, C.; Pinto, M.M. Enantioresolution of chiral derivatives of xanthones on (s,s)-whelk-o1 and 1 -phenylglycine stationary phases and chiral recognition mechanism by docking approach for (s,s)-whelk-o1. Chirality 2013, 25, 89-100. [CrossRef] [PubMed]

158. Carraro, M.L.; Palmeira, A.; Tiritan, M.E.; Fernandes, C.; Pinto, M.M.M. Resolution, determination of enantiomeric purity and chiral recognition mechanism of new xanthone derivatives on (s,s)-whelk-o1 stationary phase. Chirality 2017, 1-10. [CrossRef] [PubMed]

159. Fernandes, C.; Pinto, M.M.M.; Tiritan, M.E. Enantioresolution of chiral derivatives of xanthones on different types of liquid chromatography stationary phases: a comparative study. Curr. Chromatogr. 2014, 1, 139-150. [CrossRef]

160. Fernandes, C.; Palmeira, A.; Ramos, I.I.; Carneiro, C.; Afonso, C.; Tiritan, M.E.; Cidade, H.; Pinto, P.C.A.G.; Saraiva, M.L.M.F.S.; Reis, S.; et al. Chiral derivatives of xanthones: Investigation of the effect of enantioselectivity on inhibition of cyclooxygenases (cox-1 and cox-2) and binding interaction with human serum albumin. Pharmaceuticals 2017, 10, 50. [CrossRef] [PubMed]

161. Fernandes, C.; Oliveira, L.; Tiritan, M.E.; Leitao, L.; Pozzi, A.; Noronha-Matos, J.B.; Correia-de-Sá, P.; Pinto, M.M. Synthesis of new chiral xanthone derivatives acting as nerve conduction blockers in the rat sciatic nerve. Eur. J. Med. Chem. 2012, 55, 1-11. [CrossRef]

162. Lopes, A.; Martins, E.; Silva, R.; Pinto, M.M.M.; Remião, F.; Sousa, E.; Fernandes, C. Chiral thioxanthones as modulators of p-glycoprotein: Synthesis and enantioselectivity studies. Molecules 2018, 23, 626. [CrossRef]

163. Marona, H. Synthesis and anticonvulsant effects of some aminoalkanolic derivatives of xanthone. Pharmazie 1998, 53, 672-676.

164. Marona, H. Evaluation of some 2-substituted derivatives of xanthone for anticonvulsant properties. Pharmazie 1998, 53, 405-409.

165. Marona, H.; Gorka, Z.; Szneler, E. Aminoalkanolic derivatives of xanthone with potential antiepileptic activity. Pharmazie 1998, 53, 219-223.

166. Marona, H.; Pękala, E.; Antkiewicz-Michaluk, L.; Walczak, M.; Szneler, E. Anticonvulsant activity of some xanthone derivatives. Bioorg. Med. Chem. 2008, 16, 7234-7244. [CrossRef]

167. Marona, H.; Pekala, E.; Filipek, B.; Maciag, D.; Szneler, E. Pharmacological properties of some aminoalkanolic derivatives of xanthone. Pharmazie 2001, 56, 567. [PubMed]

168. Marona, H.; Szkaradek, N.; Karczewska, E.; Trojanowska, D.; Budak, A.; Bober, P.; Przepiórka, W.; Cegla, M.; Szneler, E. Antifungal and antibacterial activity of the newly synthesized 2-xanthone derivatives. Archiv. Der. Pharmazie 2009, 342, 9-18. [CrossRef] [PubMed]

169. Marona, H.; Szkaradek, N.; Rapacz, A.; Filipek, B.; Dybała, M.; Siwek, A.; Cegła, M.; Szneler, E. Preliminary evaluation of pharmacological properties of some xanthone derivatives. Bioorg. Med. Chem. 2009, 17, 1345-1352. [CrossRef] [PubMed]

170. Klesiewicz, K.; Żelaszczyk, D.; Trojanowska, D.; Bogusz, B.; Małek, M.; Waszkielewicz, A.; Szkaradek, N.; Karczewska, E.; Marona, H.; Budak, A. Preliminary antifungal activity assay of selected chlorine-containing derivatives of xanthone and phenoxyethyl amines. Chem. Biol. Drug. Des. 2018, 92, 1867-1875. [CrossRef] [PubMed]

171. Waszkielewicz, A.M.; Słoczyńska, K.; Pękala, E.; Żmudzki, P.; Siwek, A.; Gryboś, A.; Marona, H. Design, synthesis, and anticonvulsant activity of some derivatives of xanthone with aminoalkanol moieties. Chem. Biol. Drug. Des. 2017, 89, 339-352. [CrossRef] [PubMed]

172. Klesiewicz, K.; Karczewska, E.; Budak, A.; Marona, H.; Szkaradek, N. Anti-helicobacter pylori activity of some newly synthesized derivatives of xanthone. J. Antibiot. 2016, 69, 825-834. [CrossRef] [PubMed] 
173. Kubacka, M.; Szkaradek, N.; Mogilski, S.; Pańczyk, K.; Siwek, A.; Gryboś, A.; Filipek, B.; Żmudzki, P.; Marona, H.; Waszkielewicz, A.M. Design, synthesis and cardiovascular evaluation of some aminoisopropanoloxy derivatives of xanthone. Bioorg. Med. Chem. 2018, 26, 3773-3784. [CrossRef]

174. Szkaradek, N.; Rapacz, A.; Pytka, K.; Filipek, B.; Zelaszczyk, D.; Szafrański, P.; Słoczyńska, K.; Marona, H. Cardiovascular activity of the chiral xanthone derivatives. Bioorg. Med. Chem. 2015, 23, 6714-6724. [CrossRef]

175. Librowski, T.; Czarnecki, R.; Jastrzebska-Wiesek, M.; Opoka, W.; Marona, H. The influence of some aminoalkanolic xanthone derivatives on central nervous and cardiovascular systems in rodents. Boll. Chim. Farm 2004, 143, 267-274.

176. Szkaradek, N.; Gunia, A.; Waszkielewicz, A.M.; Antkiewicz-Michaluk, L.; Cegła, M.; Szneler, E.; Marona, H. Anticonvulsant evaluation of aminoalkanol derivatives of 2-and 4-methylxanthone. Bioorg. Med. Chem. 2013, 21, 1190-1198. [CrossRef]

177. Rajtar, G.; Zolkowska, D.; Kleinrok, Z.; Marona, H. Pharmacological properties of some xanthone derivatives. Acta Pol. Pharm. 1999, 56, 311-318. [PubMed]

178. Jastrzêbska-Wiêsek, M.; Librowski, T.; Czarnecki, R.; Marona, H.; Nowak, G. Central activity of new xanthone derivatives with chiral center in some pharmacological tests in mice. Pol. J. Pharmacol. 2003, 55, 461-466. [PubMed]

179. Jastrzebska-Wiesek, M.; Czarnecki, R.; Marona, H. The anticonvulsant, local anesthetic and hemodynamic properties of some chiral aminobutanol derivatives of xanthone. Acta Pol. Pharm. 2008, 65, 591-600. [PubMed]

180. Librowski, T.; Czamecki, R.; Jastrzebska, M. Chiral 2-amino-1-butanol xanthone derivatives as potential antiarrhythmic and hypotensive agents. Acta Pol. Pharm. 1999, 56, 87-90. [PubMed]

181. Rajtar, G.; Zolkowska, D.; Kleinrok, Z.; Marona, H. Antiplatelets activity of some xanthone derivatives. Acta Pol. Pharm. 1999, 56, 319-324. [PubMed]

182. Słoczyńska, K.; Pękala, E.; Wajda, A.; Węgrzyn, G.; Marona, H. Evaluation of mutagenic and antimutagenic properties of some bioactive xanthone derivatives using vibrio harveyi test. Lett. Appli. Microbiol. 2010, 50, 252-257. [CrossRef] [PubMed]

183. Sypniewski, D.; Szkaradek, N.; Loch, T.; Waszkielewicz, A.M.; Gunia-Krzyżak, A.; Matczyńska, D.; Sołtysik, D.; Marona, H.; Bednarek, I. Contribution of reactive oxygen species to the anticancer activity of aminoalkanol derivatives of xanthone. Invest. New Drugs 2018, 36, 355-369. [CrossRef] [PubMed]

184. Chen, X.; Leng, J.; Rakesh, K.P.; Darshini, N.; Shubhavathi, T.; Vivek, H.K.; Mallesha, N.; Qin, H.-L. Synthesis and molecular docking studies of xanthone attached amino acids as potential antimicrobial and anti-inflammatory agents. Med. Chem. Commun. 2017, 8, 1706-1719. [CrossRef] [PubMed]

185. Rakesh, K.P.; Darshini, N.; Manukumar, H.M.; Vivek, H.K.; Prasanna, D.S.; Mallesha, N. Xanthone conjugated amino acids as potential anticancer and DNA binding agents: Molecular docking, cytotoxicity and sar studies. Anticancer Agents Med. Chem. 2018. [CrossRef] [PubMed]

186. Szkaradek, N.; Stachura, K.; Waszkielewicz, A.; Cegla, M.; Szneler, E.; Marona, H. Synthesis and antimycobacterial assay of some xanthone derivatives. Acta Pol. Pharm. 2008, 65, 21-28. [PubMed]

187. Marona, H.; Szkaradek, N.; Kubacka, M.; Bednarski, M.; Filipek, B.; Cegla, M.; Szneler, E. Synthesis and evaluation of some xanthone derivatives for anti-arrhythmic, hypotensive properties and their affinity for adrenergic receptors. Archiv. der Pharmazie 2008, 341, 90-98. [CrossRef] [PubMed]

188. Marona, H.; Librowski, T.; Cegła, M.; ERDOĞAN, C.; Sahin, N.O. Antiarrhythmic and antihypertensive activity of some xanthone derivatives. Acta Pol. Pharm. Drug Res. 2008, 65, 383-390.

189. Szkaradek, N.; Rapacz, A.; Pytka, K.; Filipek, B.; Siwek, A.; Cegła, M.; Marona, H. Synthesis and preliminary evaluation of pharmacological properties of some piperazine derivatives of xanthone. Bioorg. Med. Chem. 2013, 21, 514-522. [CrossRef] [PubMed]

190. Waszkielewicz, A.; Gunia, A.; Szkaradek, N.; Pytka, K.; Siwek, A.; Satała, G.; Bojarski, A.; Szneler, E.; Marona, H. Synthesis and evaluation of pharmacological properties of some new xanthone derivatives with piperazine moiety. Bioorg. Med. Chem. Lett. 2013, 23, 4419-4423. [CrossRef] [PubMed]

191. Rapacz, A.; Sapa, J.; Nowiński, L.; Mogilski, S.; Pytka, K.; Filipek, B.; Siwek, A.; Szkaradek, N.; Marona, H. Biofunctional studies of new 2-methoxyphenylpiperazine xanthone derivatives with $\alpha 1$-adrenolytic properties. Phytochem. Rep. 2015, 67, 267-274. [CrossRef] [PubMed] 
192. Rapacz, A.; Sapa, J.; Pytka, K.; Dudek, M.; Filipek, B.; Szkaradek, N.; Marona, H. Antiarrhythmic activity of new 2-methoxyphenylpiperazine xanthone derivatives after ischemia/reperfusion in rats. Phytochem. Rep. 2015, 67, 1163-1167. [CrossRef] [PubMed]

193. Cheng, Y.-W.; Kang, J.-J. Mechanism of vasorelaxation of thoracic aorta caused by xanthone. Eur. J. Pharmacol. 1997, 336, 23-28. [CrossRef]

194. Cherkadu, V.; Kalavagunta, P.K.; Ningegowda, M.; Shivananju, N.S.; Madegowda, M.; Priya, B.S. Fecl3-catalyzed three-component one-pot synthesis of novel 4-[(benzo[d]thiazol-2-ylamino)(phenyl) methyl]-3-hydroxy-9h-xanthen-9-ones. Synlett 2016, 27, 1116-1120. [CrossRef]

2019 by the authors. Licensee MDPI, Basel, Switzerland. This article is an open access article distributed under the terms and conditions of the Creative Commons Attribution (CC BY) license (http:/ / creativecommons.org/licenses/by/4.0/). 